\title{
Strontium isotope dating of bivalve faunas from the Upper Miocene Cacela Formation, eastern Algarve, Portugal: evidence from Messinian bivalve fauna
}

\author{
Barbara STUDENCKA ${ }^{1},{ }^{*}$ and Grzegorz ZIELIŃSKI ${ }^{2}$ \\ 1 Polish Academy of Sciences Museum of the Earth in Warsaw, Al. Na Skarpie 20/26, 00-488 Warszawa, Poland \\ 2 Polish Geological Institute - National Research Institute, Rakowiecka 4, 00-975 Warszawa, Poland
}

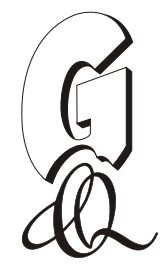

Studencka B. and Zieliński G. (2013) Strontium isotope dating of bivalve faunas from the Upper Miocene Cacela Formation, eastern Algarve, Portugal: evidence from Messinian bivalve fauna. Geological Quarterly, 57 (4): 665-686, doi: 10.7306/gq.1118

The study is focused on the determination of the geological age of bivalve fauna recovered from four fossiliferous sequences in the Cacela Formation of Algarve, southern Portugal, by means of the strontium isotope stratigraphy. Forty two analyses of bivalve samples from Barroquinha, Cabanas, the Cacela River and Lacem were performed. The estimated age based on the ${ }^{87} \mathrm{Sr} /{ }^{86} \mathrm{Sr}$ ratios in bivalve shell samples from the Cacela River (a reference section for the Cacela Formation) is $7.6 \pm 0.4 \mathrm{Ma}$ and is consistent with a late Tortonian age suggested by micropalaeontological data (calcareous nannofossils and planktonic foraminifers). Moreover, strontium isotopic data record that the oldest age of the bivalves of the Cacela Formation (Lacem site) is at least $8.9 \pm 0.4$ Ma whilst the age of about 7.0 $\pm 0.5 \mathrm{Ma}$ can be inferred for bivalves from Barroquinha. An intriguing new datum comes, however, from the bivalve strontium isotopic data of the Cabanas section which records the estimated age of about $6.7 \pm 0.4 \mathrm{Ma}$ and, therefore, an early Messinian age. This is the first report of the early Messinian marine bivalve fauna in Portugal. Sixty one bivalve species have been recovered in the Messinian of Cabanas. Four of them: Pseudopythina macandrewi (P. Fischer), Coripia corbis (Philippi), Glossus (Glossus) humanus (Linnaeus) and Cyathodonta dollfusi (Cossmann et Peyrot) have previously not been reported from the Miocene of southern Portugal.

Key words: Bivalvia, Cacela Formation, ${ }^{87} \mathrm{Sr} /{ }^{86} \mathrm{Sr}$ geochronology, Messinian, Portugal.

\section{INTRODUCTION}

The Upper Miocene sediments of the Cacela Formation are scattered along the Atlantic frontage of eastern Algarve, southern Portugal (Fig. 1) and only a few localities have yielded diverse molluscan fauna. The most important is the Cacela River (Ribeira de Cacela) sequence, the reference section of the Cacela Formation, that has attracted the attention of researchers for over 150 years (Pereira da Costa, 1866-1867; Dollfus et al., 1903; Berkeley Cotter, 1904; Chavan, 1940, 1944; Veiga Ferreira, 1951; Freneix, 1957; Glibert and Van de Poel, 1965-1970; González Delgado et al., 1995; Santos and Boski, 1998; Santos, 2000; Rico-Garcia et al., 2006; Santos and Mayoral, 2007) because of high species diversity and unique, excellent shell preservation (Pereira da Costa, 1866-1867; Dollfus et al., 1903; Veiga Ferreira, 1951; Santos, 2000). Thereafter, this famous outcrop became one of the Southern European-North African key sections for the analysis of the molluscan

\footnotetext{
* Corresponding author, e-mail: bstudencka@go2.pl
}

Received: January 18, 2013; accepted: July 26, 2013; first published online: September 18, 2013 biodiversity of the Late Miocene and the faunistic change at the Miocene-Pliocene transition. Despite an overwhelming number of studies, the knowledge of these molluscan fauna is far from complete and is in need of comprehensive modern systematic revision.

In 2002, the senior author undertook the fieldwork with the prime aim of completing the bivalve collection from outcrops in the vicinity of the village of Cacela Velha, described by Bourcart and Zbyszewski (1940), and by Cachão in his unpublished Ph.D. thesis (1995a). The location of few fossiliferous sites of the pioneer geological studies (e.g., the Monte Alto site) has not been verified by the field observations and therefore the work has focused on three bivalve collections gathered respectively from two outcrops cited by Cachão (1995a), i.e. Cabanas, close to "Forte de Sao João da Barra" and Ribeira de Barroquinha, and the new site at Lacem.

The biodiversity and environmental significance of this new fauna appears to be the same as that of the Cacela River outcrop. The age of this fauna was, however, unknown because of the scarcity of biostratigraphic records (cf. Antunes and Pais, 1992; Cachão, 1995a; Legoinha, 2003). The knowledge of the age of the cited sections would have been of fundamental importance to close the disputed question of the age of the Cacela Formation, which was crucial for understanding the palaeontological and geological history of the Algarve region 


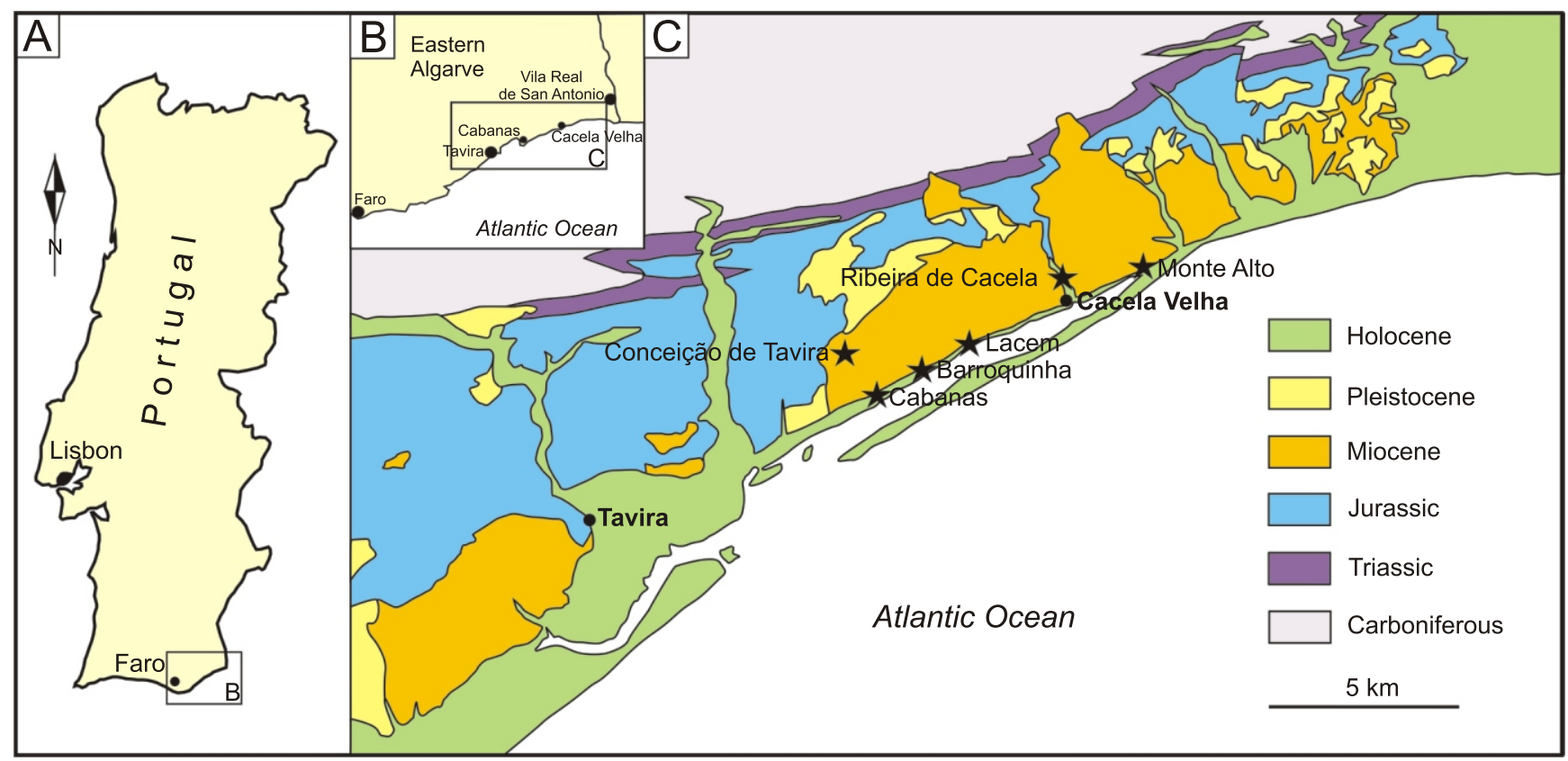

Fig. 1. Location map

A - general location of study area; B - map of eastern Algarve; C -simplified geological map of eastern Algarve adopted from Manupella (1992); asterisks - fossiliferous sites yielding bivalve material discussed in this paper

which, in turn, was closely related to the Late Miocene evolution of the Guadalquivir Basin.

To help resolve these stratigraphic uncertainties and provide a better temporal framework for palaeontological interpretations, the application of strontium isotope stratigraphy was carried out on bivalve shells from the newly explored outcrops and those from the Cacela River. This application is based on three principles. The first holds that the ${ }^{87} \mathrm{Sr} /{ }^{86} \mathrm{Sr}$ ratio in seawater, at any point in time, has always been homogenous throughout the oceans. The second assumes that the ${ }^{87} \mathrm{Sr} /{ }^{86} \mathrm{Sr}$ ratio has varied systematically through geological time. The third supposes that the ${ }^{87} \mathrm{Sr} /{ }^{86} \mathrm{Sr}$ ratio is faithfully preserved in marine carbonate precipitated directly from seawater (Hodell and Woodruff, 1994; Oslick et al., 1994; McArthur et al., 2001).

\section{GEOLOGICAL FRAMEWORK AND LITHOSTRATIGRAPHY}

During the Miocene, the Eastern Algarve Basin formed the westernmost marginal part of the Atlantic Guadalquivir Basin. At that time, the Guadalquivir Basin with several Iberian basins, which existed in the area of the Betides, acted as the northern passage between the Mediterranean Sea and the Atlantic Ocean (Esteban et al., 1996; Betzler et al., 2006). The evolution of these, relatively short-lived seaways, were controlled largely by tectonic activity (Martin et al., 2001). In the middle Tortonian, dextral rotation of the Betic Foredeep Basin caused an important palaeogeographic change in the Guadalquivir Basin (Sierro et al., 1990) induced by westward migration of the depositional centre. Considerable thickness of marine sediments deposited in the Guadalquivir Basin in middle-late Tortonian, according to Cachão and Silva (2000: p. 306), “....produced a lithostatic load, which seems to have induced subsidence farther west resuming the Neogene marine sedimentation in the eastern Algarve during the Late Tortonian". In fact, the depositional history of the
Algarve Basin was closely related to the Late Miocene development of the Guadalquivir Basin. A more detailed account on the tectonic history of the Algarve area has been provided by Ribeiro et al. (1990, 1996), Sierro et al. (1990), Cachão and Silva (1992, 2000), Kullberg et al. (1992), and summarized by Pais et al. (2012).

From the Late Miocene onwards, southern and eastern Iberia was affected by NNW-SSE compression (Sanz de Galdeano, 2000) and the Iberian gateways became progressively reduced in number and extent. In the late Tortonian, the connection between the Mediterranean Sea to the Atlantic Guadalquivir Basin was mainly through the Guadix and Granada basins (see e.g., Esteban et al., 1996; Betzler et al., 2006). By the end of the Tortonian, only the Guadalhorce Strait (existed between 7.2 and $6.3 \mathrm{Ma}$ ) acted as a major outflow channel of the Mediterranean water (Martin et al., 2001). After its closure, prior to the Messinian salinity crisis, the Guadalquivir Basin was under sole Atlantic influence.

The Upper Miocene sequence from the Atlantic frontage, cropping out in Algarve, is distinguished as the Cacela Formation (Antunes et al., 1990; Antunes and Pais, 1992; Cachão, 1995a, b, c; Cachão et al., 1998; Pais et al., 2000, 2012). It is composed mainly of fine- to very fine-grained unstratified muddy sandstone with an admixture of glauconitic siltstone and clay, and with thin sandy mudstone intercalations. The Cacela Formation occurs now as isolated patches due to the post-Miocene erosion but its widely scattered occurrence indicates formerly extensive distribution (Manuppella, 1992; Cachão, 1995a; Cachão and Silva, 2002; Fig. 1). Several studies have identified an upward change, both in sedimentary facies and micropalaeontological content, allowing the Cacela Formation to be divided into three members (Cachão et al., 1998). The coastal cliff sections in eastern Algarve, representing only the lower and middle members approximately $30 \mathrm{~m}$ thick (Cachão 1995a, c; Cachão and Silva, 2002), have been regarded as late Tortonian to earliest Messinian in age (Antunes and Pais, 1992; Cachão et al., 1998; Pais et al., 2000, 2012; Legoinha, 2003). 
The exposures of the Cacela Formation, however, are fragmented, thus making stratigraphic studies difficult. The most complete section crops out in the Cacela River (Ribeira de Cacela). The lower member ("Conglomerados e areolas fossiliferous de Ribeira de Cacela" after Cachão et al., 1998) unconformably overlies the Triassic strata (Berkeley Cotter, 1904; Choffat, 1950; Antunes and Pais, 1992) and constitutes shallow-marine deposits containing abundant marine fauna. According to Cachão (1995a), and Cachão and Silva (2002), only the lower member of the Cacela Formation contains bivalve records. The middle member ("Areolas e argilites de Cacela Fabrica" of Cachão et al., 1998) is lithologically similar, with the difference lying mainly in the sediment grain size and scarcity of macrofossils (Cachão and Silva, 2002).

The field observations made by the senior author on the Cacela River section proved that bivalve fauna occurs not only in the lower part of the Cacela Formation as suggested by Cachão (1995a) but also in the upper part of the sequence (middle member of the Cacela Fm.) which has been regarded by Pais et al. (2000, 2012) as early Messinian in age. Numerous bivalves dominated by articulated shells of the tellinid species Peronaea planata (Linnaeus) occur throughout the Cacela River section, i.e. in both lower and middle members after Cachão et al. (1998). Diagenetic processes of aragonite dissolution had strongly influenced the quality of shell preservation. In contrast to excellently preserved shells from the lower part of the Cacela River sequence (Fig. 2D, E), which display all details of sculpturing and traces of original pigmentation, those from the upper part are heavily dissolved and usually preserved as thin calcareous coverings or external moulds (Fig. 2C). This is probably the reason why the bivalves of the upper part of the Cacela River section were previously largely neglected.

\section{BIOSTRATIGRAPHIC DATA}

Both calcareous nannoplankton and planktonic foraminifera were studied to clarify the stratigraphic position of the Cacela Formation (Antunes et al., 1981, 1990; Antunes and Pais, 1992; Cachão, 1995a, b; Sierro, 1985; Sierro et al., 1993; Legoinha, 2003). Several isolated occurrences were examined but efforts have been concentrated mainly on the Cacela River section, this representing the most fossiliferous sequence in Algarve.

\section{FORAMINIFERA}

Based on planktonic foraminifers detected in the Cacela River section, Antunes and Pais (1992) referred the lower member of the Cacela Formation to the N16 and N17 zones of Blow (late Tortonian). Owing to insufficient data (rare and poor preservation of foraminiferal tests), the authors only hypothesized an early Messinian age of both the middle and upper members of the Cacela Formation.

More recently, taxonomic and biostratigraphic studies were performed by Legoinha (2003). The distribution coiling pattern of the keeled globorotaliids within the Cacela Formation was used to correlate the Portuguese sedimentary record with that of the

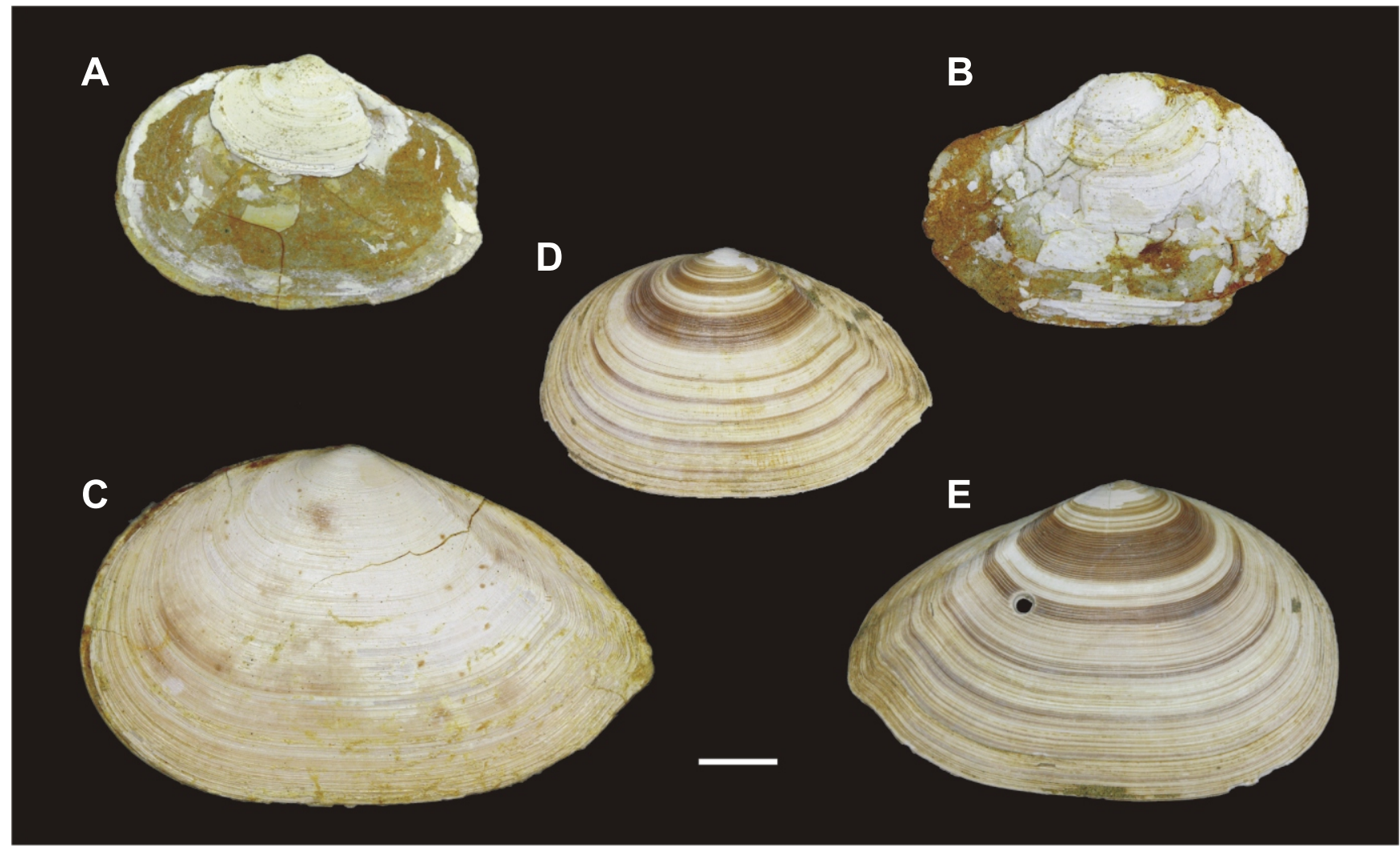

Fig. 2. Preservation state of Peronaea planata (Linnaeus, 1758) shells from the Cacela Formation

A, B - composite mould with partial shell preservation, Unit B, Cabanas: A - exterior of left valve (MZ VIII MI-3719/1), B - exterior of right valve (MZ VIII MI-3719/2); C - articulated shell with partly dissolved outer layer (MZ VIII MI-3762), upper part of the Cacela River section (3 $\mathrm{m}$ above layer 3 of Santos, 2000); D, E - exterior view of well-preserved valve with traces of original pigmentation, lower part of the Cacela River section (layer 3 of Santos, 2000): D - left valve (MZ VIII MI-3763/1), E - right valve (MZ VIII MI-3763/2); scale bar - 10 mm 
Guadalquivir Basin, studied in greater detail by Sierro (1985) and Sierro et al. $(1987,1993)$ as well as with the Abad composite section in the Sorbas Basin discussed by Sierro et al. (2001). On the one hand, Legoinha (2003) cited the Globorotalia menardii (d'Orbigny) sinistral coiling group in the lowest part of the Cacela River section and identified the bioevent 1 of Sierro (1985) in the middle part of the same section, immediately above the level yielding bivalve fauna described by Santos (2000) and listed by Santos and Boski (1998), and by Santos and Mayoral (2007). Considering that the Sierro bioevent 1 approximates chronologically the massive disappearance of the Globorotalia menardii sinistral coiling group, calibrated in the Guadalquivir Basin at $7.512 \mathrm{Ma}$ (Sierro et al., 2001), it follows that the lower part of the Cacela Formation has to be interpreted again as late Tortonian in age. On the other hand, Legoinha (2003) recognized the bioevent 3 of Sierro (1985) within the Cacela Formation at the Quelfes section, $10 \mathrm{~km}$ east of Faro. This latter event, calibrated in the Guadalquivir Basin at 7.25 Ma (Sierro et al., 2001), has allowed defining an early Messinian age of the upper part of the Cacela Formation. No data are available for the Cacela Formation at the Barroquinha, Cabanas and Lacem sections.

\section{CALCAREOUS NANNOPLANKTON}

The nannoplankton flora content of the Cacela Formation is known through the study by Cachão (1995a). Samples from the Cacela River, Ribeira de Barroquinha and from the cliff near Cabanas at "Forte de Sao João da Barra" sections yielded stratigraphically useful associations indicating the Discoaster quinqueramus Zone (NN11 in the zonal scheme of Martini, 1971 or Zone CN9 of Okada and Bukry, 1980) which embraces the late Tortonian-Messinian interval between about 8.2 and $5.53 \mathrm{Ma}$ (Backman et al., 2012). Moreover, the co-occurrence of the two most important and diagnostic species Minylitha convallis Bukry (with its LAD calibrated at 7.8 Ma according to Berggren et al., 1995) and Discoaster berggrenii Bukry (with its FAD calibrated at 8.6 Ma according to Berggren et al., 1995) was documented at the base of the Cacela River section. According to the new biozonation presented recently by Backman et al. (2012), the subzone CN9a of Okada and Bukry (1980) corresponds to Zone CNM16 - Discoaster bergrenii Base Zone of which estimated age is between 8.20 and $7.39 \mathrm{Ma}$. These data clearly suggest that the bivalve fauna described by Santos (2000) listed by Santos and Boski (1998) and discussed by Gonzalez Delgado et al. (1995), Rico-Garcia et al. (2006), and by Santos and Mayoral (2007) is late Tortonian in age.

The nannofossils recorded at the bottom of the section at "Forte de Sao João da Barra" containing Discoaster berggrenii and Discoaster quinqueramus have been also referred to subzone CN9a notwithstanding that Minylitha convallis has not been found in the samples examined (Cachão, 1995a). Moreover, Cachão (1995a) also ascribed the base of the section at Ribeira de Barroquinha to the CN9a on the basis of the presence of $D$. quinqueramus. Eventually, all the biostratigraphic data confirm late Tortonian age for the lower part of the Cacela River section, without excluding, Messinian age for the top level of the Cacela Formation.

\section{LITHOLOGY AND BIVALVE CONTENTS OF THE STUDIED FOSSILIFEROUS SITES}

Three isolated occurrences of the Cacela Formation (Cabanas, Barroquinha and Lacem sites) were studied to obtain the bivalve material. They are located along the southeastern coast of Algarve between the villages of Cabanas to the west and Cacela Velha to the east (Fig. 1). Although Cachão (1995a) gave a brief account on the presence of the molluscan fauna in two sections observed near the village of Cabanas ("Forte de Sao João da Barra" and Barroquinha), their taxonomic content has never been studied in detail and no bivalve material has been collected prior to the current study. All these outcrops are very rich in molluscs, in particular in bivalves. The newly collected material is deposited at the Polish Academy of Sciences Museum of the Earth in Warsaw, Poland (abbr. MZ) under the catalogue numbers MZ VIII MI 3680 - MZ VIII MI 3745 and in the Centre for Marine and Environmental Studies (CIMA), University of Algarve, Faro, Portugal. The list of bivalves recorded from Unit B at the Cabanas site is reported in Table 1.

\section{CABANAS}

The Cacela Formation is exposed in the immediate vicinity of Cabanas, along the coastal cliff east of "Forte de Sao João da Barra". The exposed section at Cabanas attains a thickness of $10.0-12.0 \mathrm{~m}$. The following four units can be distinguished based on lithological features and fossil bivalves content (Fig. 3).

Unit A. - Dark grey, 0.1-0.4 m thick silt-clayey coquina which crops out in the modern inter-tidal area can be observed only during the low tide along the sea cliff just east of "Forte de Sao João da Barra" up to the Barroquinha stream. The coquina is dominated by large, well-preserved and disarticulated shells of Ostrea edulis Linnaeus, with rare moulds of large-sized thick-shelled species Glycymeris (Glycymeris) bimaculata (Poli), Megacardita jouanneti (Basterot) and Pelecyora (Cordiopsis) gigas (Lamarck). The base of the coquina layer is not exposed while its top is destroyed by present-day erosion and largely covered by Holocene lagoon deposits and dune.

Unit B. - The sedimentary succession at the base of the cliff begins with yellowish slightly cemented very fine-grained sandstone, $1.6 \mathrm{~m}$ thick. Nowadays its base is covered by Holocene deposits but, according to Cachão (1995a), the sandstones were underlain by clays which yielded well-preserved calcareous nannoplankton. A total of 60 bivalve species have been identified in this unit that represent 48 genera belonging to 22 families of which the family Veneridae is characterized by particularly high taxonomic diversity (Table 1). The diagenetic processes of aragonite dissolution strongly influenced the quality of shell preservation; only oysters and scallops are well-preserved (Figs. 2A, B, 4B-G).

Unit C. - This unit, 0.1-0.3 $\mathrm{m}$ thick with an erosive base, consists almost entirely of shells of Ostrea edulis Linnaeus. Oyster shells are separated from each other but they are densely packed and much larger than those in the underlying layer.

Unit D. - This unit, up to $8.0 \mathrm{~m}$ thick, is composed of slightly cemented, fine- to very fine-grained sandstones that grade upward to siltstones which are intercalated with hard carbona- 
Early Messinian bivalves collected in 2002 at Cabanas from Unit B, which are housed in the Museum of the Earth in Warsaw, Poland

\begin{tabular}{|c|c|}
\hline Family & Species \\
\hline \multirow{3}{*}{ Nuculidae Gray, 1824} & Nucula (Nucula) nucleus (Linnaeus, 1758) \\
\hline & Nucula (Nucula) nitidosa Winckworth, 1930 \\
\hline & Nucula (Lamellinucula) jeffreysi Bellardi, 1875 \\
\hline Nuculanidae H. Adams et A. Adams, 1858 & Saccella commutata (Philippi, 1844) \\
\hline \multirow{3}{*}{ Arcidae Lamarck, 1809} & Anadara diluvii (Lamarck, 1805) \\
\hline & Anadara fichteli (Deshayes, 1852) \\
\hline & Anadara cf. pectinata (Brocchi, 1814) \\
\hline Pteriidae Gray, 1847 & Pteria cf. hirundo (Linnaeus, 1758) \\
\hline \multirow{5}{*}{ Pectinidae Wilkes, 1810} & "Amussium" cristatum badense (Fontannes, 1882) \\
\hline & Pecten subarcuatus Tournouër, 1874 \\
\hline & Flabellipecten fraterculus (Sowerby in Smith, 1847) \\
\hline & Talochlamys multistriata (Poli, 1795) \\
\hline & Aequipecten seniensis (Lamarck, 1758) \\
\hline Ostreidae Rafinesque, 1815 & Ostrea edulis Linnaeus, 1758 \\
\hline \multirow{6}{*}{ Lucinidae Fleming, 1828} & Linga (Linga) columbella (Lamarck, 1819) \\
\hline & Linga (Bellucina) agassizi (Michelotti, 1839) \\
\hline & Megaxinus transversus (Bronn, 1831) \\
\hline & "Lucina" unidentified species \\
\hline & Lucinoma borealis (Linnaeus, 1758) \\
\hline & Anodontia (Loripinus) fragilis (Philippi, 1836) \\
\hline Ungulinidae H. Adams et A. Adams, 1857 & Diplodonta rotundata (Montagu, 1803) \\
\hline Kellidae Forbes et Hanley, 1848 & Pseudopythina macandrewi (P. Fischer, 1867) \\
\hline \multirow{2}{*}{ Carditidae Fleming, 1828} & Megacardita jouanneti (Basterot, 1825) \\
\hline & Coripia corbis (Philippi, 1836) \\
\hline Astartidae d'Orbigny, 1844 & Astarte sp. \\
\hline \multirow{4}{*}{ Cardidae Lamarck, 1809} & Cardium indicum Lamarck, 1819 \\
\hline & Laevicardium oblongum (Gmelin, 1791) \\
\hline & Acanthocardia paucicosta (G.B. Sowerby II, 1834) \\
\hline & Discors spondyloides (Von Hauer, 1847) \\
\hline \multirow{4}{*}{ Mactridae Lamarck, 1809} & Spisula subtruncata (da Costa, 1778) \\
\hline & Lutraria (Lutraria) lutraria (Linnaeus, 1758) \\
\hline & Lutraria (Lutraria) oblonga (Gmelin, 1791) \\
\hline & Lutraria (?Psammophila) expansa Dollfus, Berkeley Cotter et Gomes, 1903 \\
\hline \multirow{6}{*}{ Tellinidae de Blainville, 1814} & Tellina (Oudardia) compressa (Brocchi, 1814) \\
\hline & Tellina (Tellinella) distorta Poli, 1791 \\
\hline & Moerella donacina (Linnaeus, 1758) \\
\hline & Peronaea planata (Linnaeus, 1758) \\
\hline & Macoma (Psammacoma) elliptica (Brocchi, 1814) \\
\hline & Gastrana fragilis (Linnaeus, 1758) \\
\hline Psammobiidae Fleming, 1828 & Gari cf. fervensis (Gmelin, 1791) \\
\hline \multirow{2}{*}{ Solecurtidae d'Orbigny, 1846} & Solecurtus cf. strigilatus (Linnaeus, 1758) \\
\hline & Azorinus chamasolen (da Costa, 1778) \\
\hline \multirow{11}{*}{ Veneridae Rafinesque, 1815} & Venus (Ventricoloidea) nux (Gmelin, 1791) \\
\hline & Circomphalus foliaceolamellosus (Dillwyn, 1817) \\
\hline & Pitar (Pitar) rudis (Poli, 1795) \\
\hline & Callista italica (Defrance, 1818) \\
\hline & Pelecyora (Cordiopsis) brocchii (Deshayes, 1836) \\
\hline & Pelecyora (Cordiopsis) islandicoides (Lamarck, 1818) \\
\hline & Dosinia lupinus (Linnaeus, 1758) \\
\hline & Dosinia exoleta (Linnaeus, 1758) \\
\hline & Paphia zbyszewskii Freneix, 1957 \\
\hline & Callistotapes vetula (Basterot, 1825) \\
\hline & Clausinella fasciata (da Costa, 1778) \\
\hline Myidea Lamarck, 1809 & Tugonia anatina (Gmelin, 1791) \\
\hline Corbulidae Lamarck, 1818 & Corbula (Varicorbula) cf. gibba (Olivi, 1792) \\
\hline Hiatellidae Gray, 1824 & Panopea (Panopea) cf. menardi (Deshayes, 1828) \\
\hline \multirow{2}{*}{ Thracidae Stoliczka, 1870} & Thracia pubescens (Pulteney, 1799) \\
\hline & Cyathodonta dollfusi (Cossmann et Peyrot, 1909) \\
\hline \multirow{2}{*}{ Cuspidariidae Dall, 1886} & Cuspidaria cuspidata (Olivi, 1792) \\
\hline & Cuspidaria rostrata (Spengler, 1793) \\
\hline
\end{tabular}



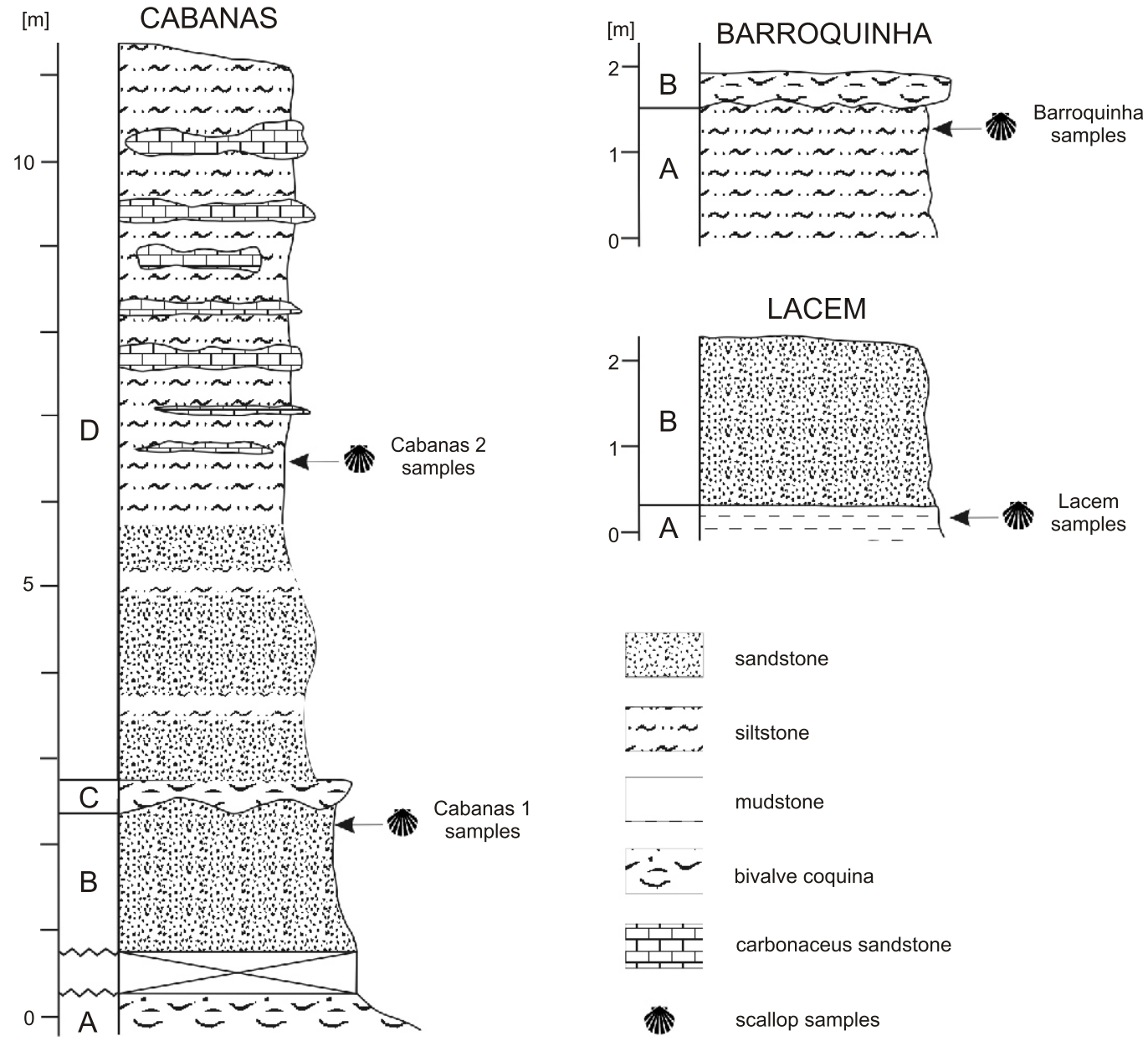

Fig. 3. Generalized sedimentological logs of the Cacela Formation at Cabanas, Barroquinha and Lacem with the position of bivalve samples for strontium isotope analysis

Details for distinguished units are given in the text (see Fig. 1 for location)

ceous sandstone lenses up to $0.3 \mathrm{~m}$ in thickness and few hundred metres in lateral extent. Scattered bivalve shells and moulds occur only in the lower part of the unit, and their diversity is very low. Five species have been identified: "Amussium" cristatum badense (Fontannes), Flabellipecten fraterculus (Sowerby), Glossus (Glossus) humanus (Linnaeus), Venus (Ventricoloidea) nux (Gmelin) and Dosinia lupinus (Linnaeus). Several large articulated shells of the scallop species Flabellipecten fraterculus have been collected just above the oyster coquina bed (Fig. 5). The occurrence of Glossus (G.) humanus is found for the first time in the Neogene of Portugal (Fig. 4A).

\section{BARROQUINHA}

A minor patch of the Cacela Formation, located in the area adjacent to the mouth of the small stream of Barroquinha, $1 \mathrm{~km}$ to the east of the Cabanas site, was the object of biostratigraphic analysis for calcareous nannoplankton by Cachão (1995a). Two units can be discriminated based on the lithological features and fossil bivalves content (Fig. 3).

Unit A. - The section begins with a $1.5 \mathrm{~m}$ thick greyish yellow siltstones (accessible only during the low tide) containing at the top a considerable accumulation of articulated shells of Callistotapes aenigmatica (Fischer et Tournouër). Fifty-four bi- valve species have been identified within material gathered from this unit. Bivalves are represented either by disarticulated or articulated valves as well as by entire or fragmented shells with well-preserved ornamentation.

Unit B. - This unit, 0.2-0.3 $\mathrm{m}$ thick hard pebble-conglomerate with an erosive base, consists almost entirely of large-sized, predominantly disarticulated, shells of Crassostrea gryphoides (Schlotheim) and Ostrea edulis Linnaeus. The top of this unit is destroyed largely by present-day erosion.

\section{LACEM}

The Cacela Formation occurs here as thin discrete remnants cropping out in the mouth of the small stream of Lacem located just opposite to the Lacem inlet, $2 \mathrm{~km}$ west of the village of Cacela Velha. This very small outcrop has never been described (cf. Cachão, 1995a; Pais et al., 2012). The exposed section attains a thickness of $2.0 \mathrm{~m}$ (Fig. 3).

Unit A. - The section begins with a $0.5 \mathrm{~m}$ thick dark greenish-brownish micaceous mudstone bearing articulated and disarticulated robust valves of Megacardita jouanneti (Basterot), Pelecyora (Cordiopsis) gigas (Lamarck) and Callista (Callista) aff. gauderndorfensis Schaffer. This unit, with its obscure base, is visible in both the stream and streamside only during the low tide. 


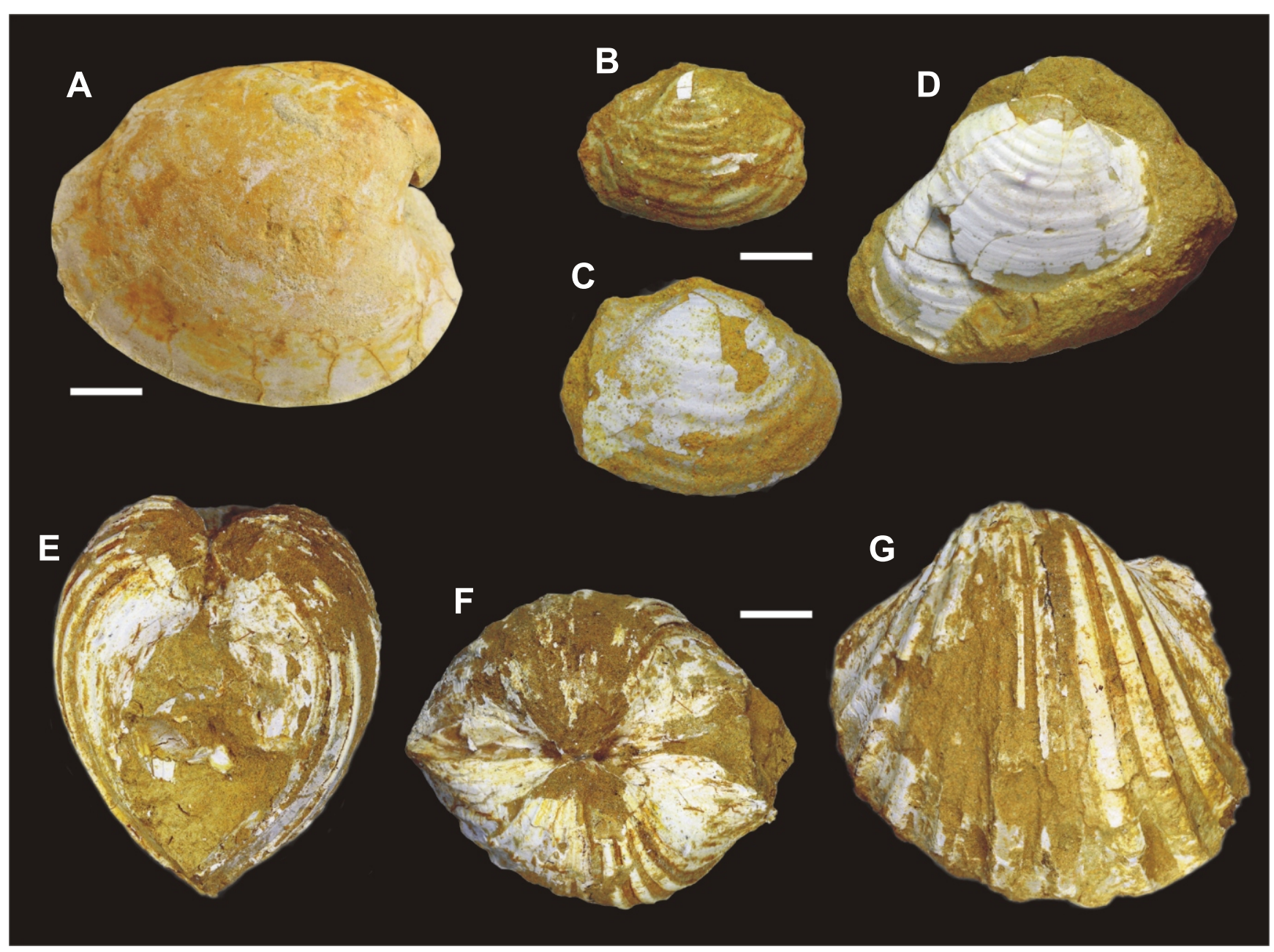

Fig. 4. Preservation state of bivalve shells from the Cacela Formation

A - Glossus (Glossus) humanus (Linnaeus, 1758), internal mould of right valve (MZ VIII MI-3725), Unit D, Cabanas; B-D - Cyathodonta dollfusi (Cossmann et Peyrot, 1909), Unit B, Cabanas: B - articulated shell with partial shell preservation, view of right valve (MZ VIII MI-3747/1), C - exterior of right valve (MZ VIII MI-3747/2), D - exterior of two left valves (MZ VIII MI-3747/3); E-G - Cardium indicum Lamarck, 1819, articulate composite mould with partial shell preservation (MZ VIII MI-3709), Unit B, Cabanas: E - posterior view, F - dorsal view, $\mathrm{G}$ - view of left valve; scale bars - $10 \mathrm{~mm}$

Unit B. - This unit is composed of a $1.5 \mathrm{~m}$ thick yellowish very fine-grained unstratified muddy sandstone containing numerous bivalves and, less commonly, gastropods. Articulated shells are very common. The burrower bivalve Tugonia anatina (Gmelin) is an important element of this fauna. Its fragile articulated shells show no evidence of post-mortem transport, such as disarticulation, fragmentation or physical erosion of shell surface. The top of this unit is destroyed by present-day erosion and largely covered by Holocene dunes.

\section{MATERIAL AND METHODS}

SAMPLE PREPARATION

Strontium isotope analyses were carried out on the bivalve samples obtained from newly explored outcrops of the Cacela Formation and those from the Cacela River sequence. All of the 21 bivalve specimens from Cabanas, Barroquinha and Lacem were recovered during the fieldwork undertaken in 2002 by the senior author with the assistance of Dr. A. Santos. The sampled levels are marked in Figure 3. Because of the poor preservation of aragonite bivalve shells gathered at Cabanas and Barroquinha, it was decided to analyse well-preserved low-Mg calcite scallop shells. In Cabanas, the valves of the species Flabellipecten fraterculus (Sowerby), Talochlamys multistriata (Poli) (Unit B) and "Amussium" cristatum badense (Fontannes) (Unit D) were selected for Sr-isotope measurements. In Barroquinha, the valves of Flabellipecten fraterculus and Talochlamys multistriata, and oyster Ostrea edulis with calcite shell, were used. Considering that some taxa of the order of Pectinoida Rafinesque retain some aragonitic structures in the right valve but not in the left one (for details see Carter, 1990), most of the samples were extracted from the left valves of Flabellipecten fraterculus. During the fieldwork in 2002, the Cacela River site was omitted in sampling due to its protected status (Santos et al., 2001). Therefore, in this case, 15 bivalve valves were selected from the collection created by A. Santos during the 1990s. The Santos collection, currently housed in the University of Huelva, contains bivalve material derived c. $300 \mathrm{~m}$ upstream from the historical site at "Ribeira de Cacela". As scallops are very rare among bivalves in both the Lacem and Cacela River sites (layer 3 of Santos, 2000; level C3 of Santos and May- 


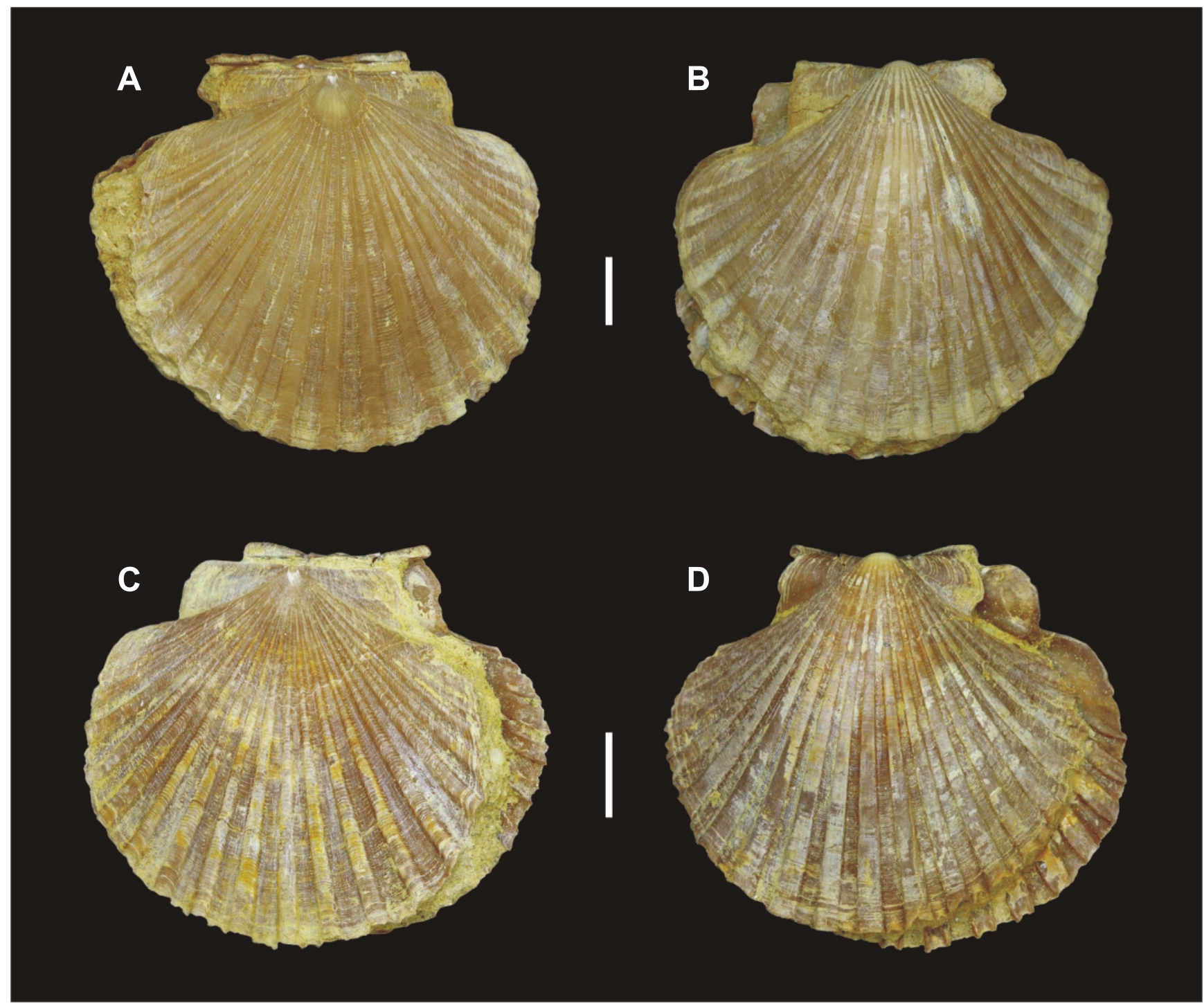

Fig. 5. Flabellipecten fraterculus (Sowerby in Smith, 1847) shells from the Cacela Formation

A, B - articulate shell (MZ VIII MI-3694/1), Unit D, Cabanas: A - exterior of left valve, B - exterior of right valve; C, D - articulated shell (MZ VIII Ml-3694/2), Unit D, Cabanas: C - exterior of left valve, D - exterior of right valve; scale bars - $10 \mathrm{~mm}$

oral, 2007), the majority of measurements for strontium isotope analyses were done on exceptionally well-preserved aragonitic shells of Peronaea planata (Linnaeus) and Clausinella fasciata (da Costa).

Prior to strontium isotope measurements, each specimen was examined microscopically for evidence of alteration or recrystallisation. In addition, to assess the potential effects of diagenesis, such methods as cathodoluminescence (CL), X-ray diffraction and AES-ICP analysis of trace elements contents (Mg, $\mathrm{Mn}, \mathrm{Fe}, \mathrm{Sr}, \mathrm{Na}$ ) were performed on selected specimens (see Brand and Veizer, 1980; Brand, 1991; Denison et al., 1994; McArthur, 1994). Scanning electron microscope inspection of broken shells helped to identify samples with well-preserved primary biogenic structures. Selected samples were cleaned in an ultrasonic bath with distilled water. The thin outer layer of each analysed shell fragment was removed and powdered.

\section{STRONTIUM ISOTOPE ANALYSIS}

Approximately $50 \mathrm{mg}$ of the powdered samples were dissolved in 2M acetic acid (see e.g., Kralik, 1984; Bailey et al., 2000 for discussion on acid leaching techniques). After $24 \mathrm{~h}$ of dissolving, the samples were centrifuged, insoluble residues removed, and clear leachates evaporated with concentrated nitric acid. Strontium separation was performed at two steps: with $100 \%$ nitric acid (Otto et al., 1988) and using cation exchange resin (Bio-Rad $50 \mathrm{~W}-\mathrm{X} 8$ with $2.5 \mathrm{M} \mathrm{HCl}$ as an eluent). Total blank of chemical procedures has been determined to be less than 1 $\mathrm{ng}$ of total Sr. For average sample weight of about $50 \mathrm{mg}$, this blank value is not enough to affect $\mathrm{Sr}$ isotopic ratio values. Analyses of strontium isotopic ratio $\left({ }^{87} \mathrm{Sr} /{ }^{86} \mathrm{Sr}\right)$ were performed using a VG Sector 54 mass spectrometer (equipped with 7 faraday collectors) at the Institute of Geological Sciences, Polish Acad- 
emy of Sciences in Warsaw, Poland. Approximately $1 \mathrm{mg}$ of pure $\mathrm{Sr}$ was loaded on tantalium filaments. All measured ratios were instrumentally corrected to fractionation effect using the value of ${ }^{86} \mathrm{Sr} /{ }^{88} \mathrm{Sr}=0.1194$ and normalized with NIST 987 isotopic standard ${ }^{87} \mathrm{Sr} /{ }^{86} \mathrm{Sr}$ ratio $=0.710248$ (Oslick et al., 1994). AnaIytical errors are equal to 2 se values (Thirlwall, 1991). In addition, for the control of chemical procedures, the sample extracted from the bivalve shell of Ervilia podolica (Eichwald), with

${ }^{87} \mathrm{Sr} /{ }^{86} \mathrm{Sr}$ ratio $=0.708592$, was used as an internal laboratory standard (Zieliński, 2002).

Some authors (Kralik, 1984; McArthur, 1994; Bailey et al. 2000) show that during chemical preparation carbonate shell samples run potential risk of contamination with strontium from other phases occurring in the analysed material (e.g., clay minerals). By this reason and for better control of chemical procedures, two tests were performed: (1) dissolution in different acids and (2) sequential dissolution.

Test 1. - The sample extracted from the Clausinella fasciata (da Costa) valve (sample GZBS 5 from the Cacela River) was divided into two parts, which were dissolved in $2 \mathrm{M}$ acetic acid and $2.5 \mathrm{M} \mathrm{HCl}$, respectively. After 24 hours, the insoluble remains were removed and solutions were analysed for $\mathrm{Sr}$ isotopic ratio.

Test 2. - This test was undertaken to assess the potential effect of time on dissolution. Powdered sample of the valve of Peronaea planata (Linnaeus) (sample GZBS 6 from the Cacela River) was divided into two parts ( $A$ and $B$ ), which were individu-
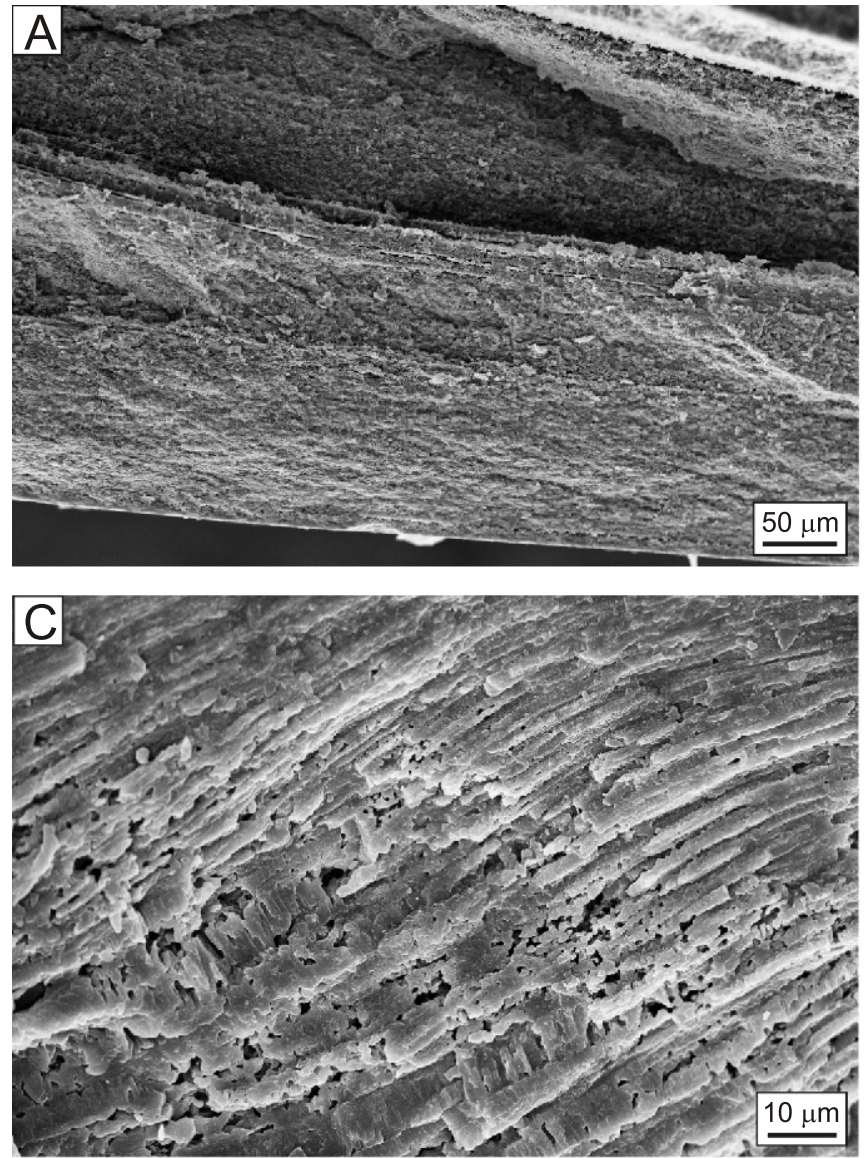

ally dissolved in two different portions of $2 \mathrm{M}$ acetic acid. Part $\mathrm{A}$ was dissolved during 24 hours to complete dissolution of the carbonate phase. Whilst part B was dissolved in the second portion of identical solution of $2 \mathrm{M}$ acetic acid, but after a specified time period $\left(t_{i}\right)$ part of solution was taken to $\mathrm{Sr}$ isotopic analysis. This operation was repeated for $t_{i}=10$ minutes, 1 hour and 4 hour of dissolution. Additionally, part of insoluble residue, which remained after 4 hours of dissolution, was also analysed.

\section{RESULTS}

\section{BIVALVE PRESERVATION}

Light microscope observations indicate that bivalve shell preservation is variable between the sites. Scanning electron microscope (SEM) inspection of several broken valves displayed well-preserved primary biogenic microstructures in calcite-built scallop shells as well as in aragonite shells. Figures 6 and 7 illustrate SEM micrographs of the unaltered aragonite shell of Peronaea planata (Linnaeus). X-ray diffraction of powdered shells indicated the presence of pure aragonite or, in case of scallop shells, pure calcite material. The trace-elemental data of selected specimens are presented in Table 2.
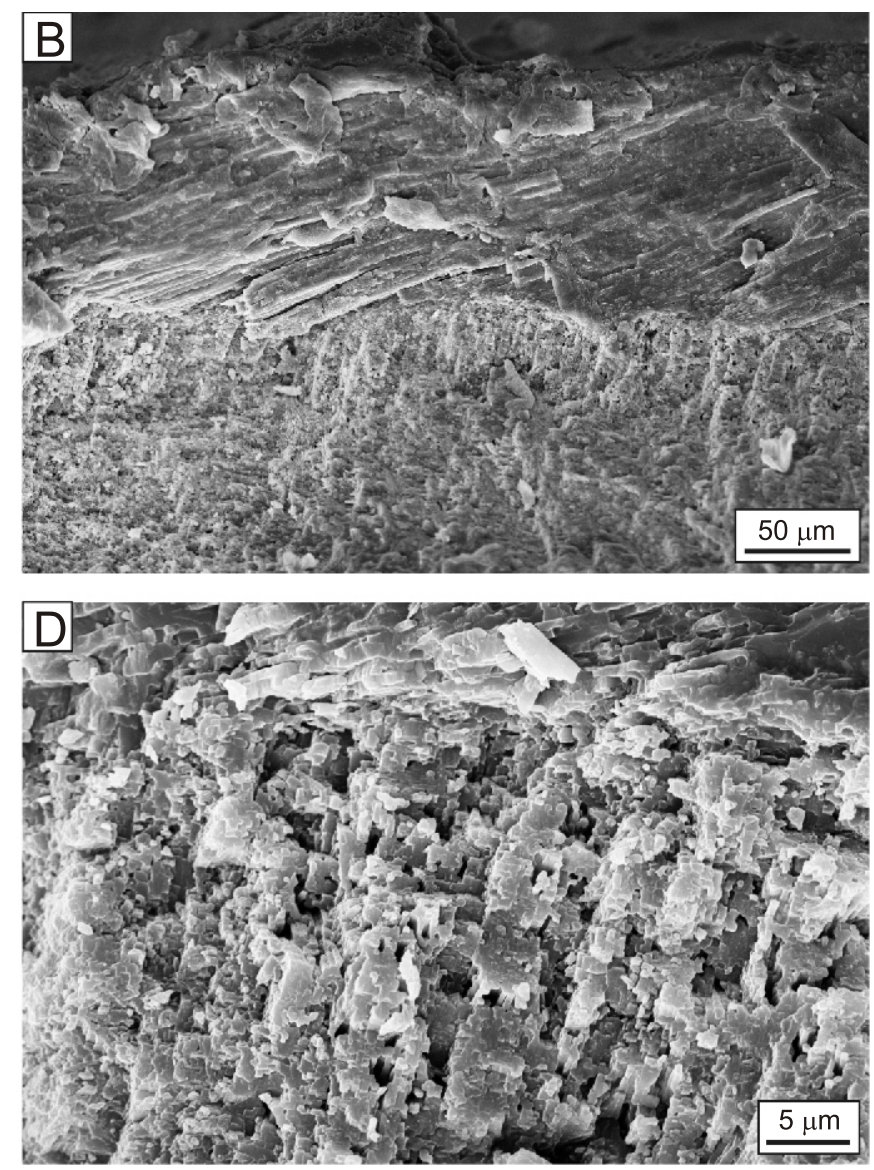

Fig. 6. SEM photomicrographs of Peronaea planata (Linnaeus, 1758) aragonitic shells, Cacela River section (layer 3 of Santos, 2000)

A - radial view of shell; $\mathbf{B}$ - contact of the outer and middle shell layer (fibrous composite prismatic and crossed-lamellar structure) in radial view of shell; $\mathbf{C}$ - fine fibrous prisms that built the outer shell layer; $\mathbf{D}$ - radial view of well-preserved aragonitic crossed-lamellar structure in the outer sublayer of the middle shell layer 

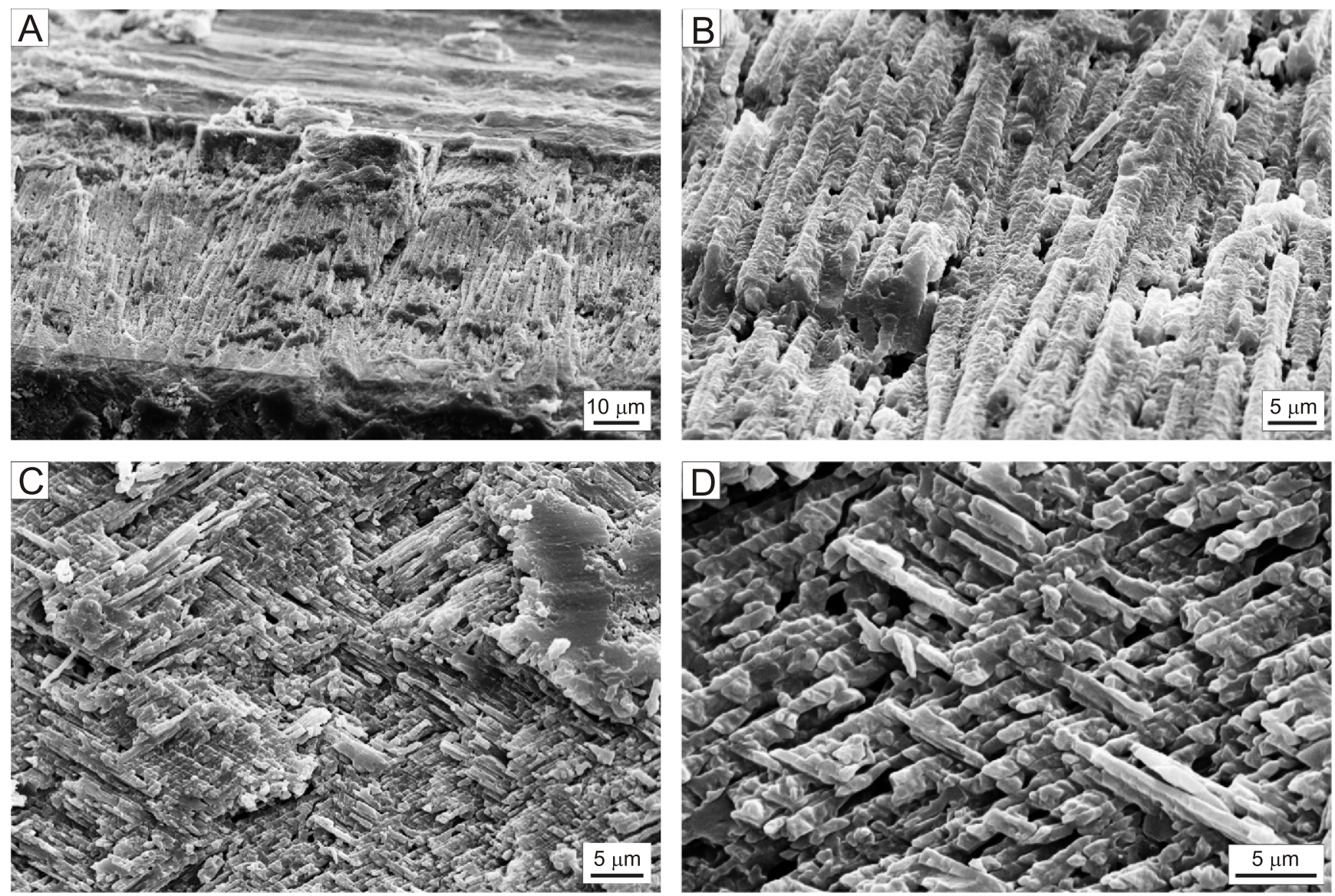

Fig. 7. SEM photomicrographs of Peronaea planata (Linnaeus, 1758) aragonitic shells, Cacela River section (layer 3 of Santos, 2000)

A - contact of the outer and middle shell layer (left bottom) in transverse view of shell, densely spaced fine concentric lines covering external surface are visible above the outer shell layer (right top); B - transverse view of fibrous composite prismatic structure of the outer shell layer; C - transverse view of well-preserved aragonitic crossed-lamellar structure in the outer sublayer of the middle shell layer; D - higher magnification of crossed-lamellar structure consisting of a series of parallel near-rectangular obliquely arranged lamellae

\section{STRONTIUM ISOTOPE DATA}

The results of two tests conducted to estimate variations in ${ }^{87} \mathrm{Sr} /{ }^{86} \mathrm{Sr}$ values of the different acids utilized to the dissolution and of the sequential dissolution showed: (1) negligible differences in ${ }^{87} \mathrm{Sr} /{ }^{86} \mathrm{Sr}$ values $(0.708945 \pm 10$ for acetic acid and $0.708951 \pm 10$ for hydrochloric acid solution) and high chemical purity of analysed shell material; (2) that (i) $4 \mathrm{~h}$ dissolving time is too short to dissolve carbonate phase: most of it stays in the solid phase, and (ii) the early fractions may contain much con- taminant $\mathrm{Sr}$ which gives higher values of ${ }^{87} \mathrm{Sr} /{ }^{86} \mathrm{Sr}$ ratios, but its proportion in total $\mathrm{Sr}$ is not significant (Fig. 8).

All results of the measured ${ }^{87} \mathrm{Sr} /{ }^{86} \mathrm{Sr}$ values of 42 bivalve samples and one Paroxystele rotellaris (Michelotti) gastropod sample from the Cacela Formation are given in Table 3. Variations of the ${ }^{87} \mathrm{Sr} /{ }^{86} \mathrm{Sr}$ ratio values observed within the samples analysed from each fossiliferous sites are presented in Figure 9.

Barroquinha. - Five scallop samples and one oyster sample were examined. As indicated in Table 3 , the ${ }^{87} \mathrm{Sr} /{ }^{86} \mathrm{Sr}$ ratio of the oyster sample (BAR 12) was significantly higher than of the

Table 2

Trace element contents in selected shell samples, determined by AES-ICP

\begin{tabular}{|l|l|c|c|c|c|c|}
\hline Sample & \multicolumn{1}{|c|}{ Species } & $\begin{array}{c}\mathrm{Fe} \\
{[\mathrm{ppm}]}\end{array}$ & $\begin{array}{c}\mathrm{Mg} \\
{[\mathrm{ppm}]}\end{array}$ & $\begin{array}{c}\mathrm{Mn} \\
{[\mathrm{ppm}]}\end{array}$ & $\begin{array}{c}\mathrm{Na} \\
{[\mathrm{ppm}]}\end{array}$ & $\begin{array}{c}\mathrm{Sr} \\
{[\mathrm{ppm}]}\end{array}$ \\
\hline BAR 7 & Flabellipecten fraterculus & 115 & 1315 & 30 & 3950 & 972 \\
\hline BAR 9 & Talochlamys multistriata & 882 & 1740 & 97 & 3460 & 1021 \\
\hline CAB 10 & Flabellipecten fraterculus & 393 & 1260 & 36 & 3880 & 956 \\
\hline CAB 11 & Flabellipecten fraterculus & 213 & 1495 & 19 & 4320 & 1034 \\
\hline CAB 14 & "Amussium" cristatum badense & 596 & 1210 & 48 & 2880 & 884 \\
\hline CAC 1 & Flabellipecten fraterculus & 166 & 900 & 19 & 3999 & 1090 \\
\hline CAC 2 & Flabellipecten fraterculus & 204 & 1150 & 23 & 4080 & 1023 \\
\hline LAC 6 & Cardium indicum & 92 & 93 & 2 & 3600 & 1925 \\
\hline
\end{tabular}

BAR - Barroquinha, CAB - Cabanas, CAC - Cacela River, LAC - Lacem 


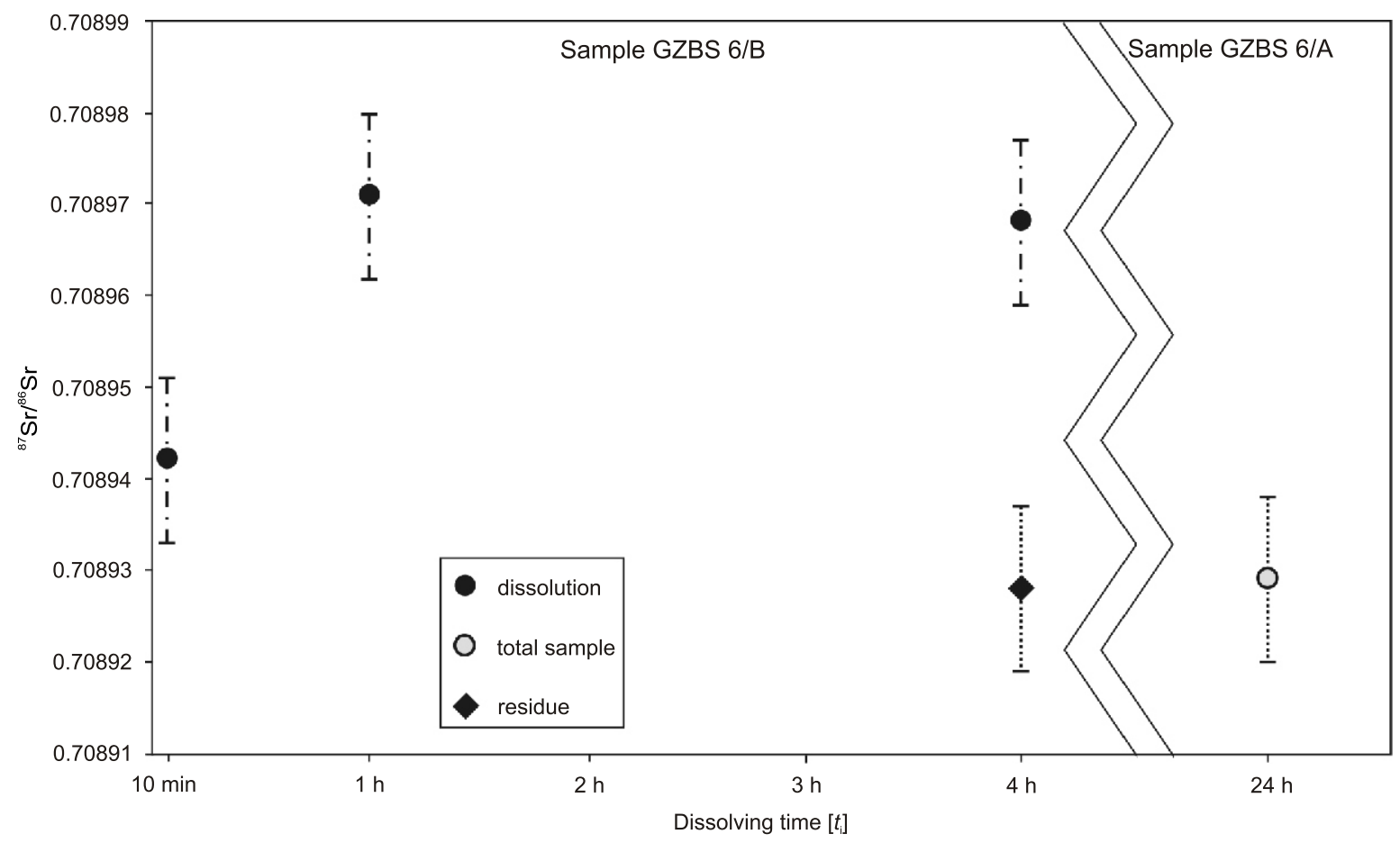

Fig. 8. Results of ${ }^{87} \mathrm{Sr} /{ }^{86} \mathrm{Sr}$ ratio measured during sequential dissolution of Peronaea planata (Linnaeus, 1758) valve (A and B parts of GZBS 6 sample) in 2M acetic acid; sequence dissolved clearly demonstrates that the strontium isotopic ratio value is conditioned by time

others; this is probably because of the presence of chalky deposits developed in its shell. This ratio was not included in age determination.

Cabanas. - Seven samples were analysed from Unit B and three from overlying Unit $\mathrm{D}$. The ${ }^{87} \mathrm{Sr} /{ }^{86} \mathrm{Sr}$ values increase from $0.708948-0.708980$ near the base of Unit B to close to 0.709011 within Unit $D$. The strontium isotope ratios measured on three Talochlamys multistriata samples derived from Unit B have less variability (0.708958-0.708968) than those measured on four Flabellipecten fraterculus samples (0.708948-0.708980) in the same unit.

Cacela River. - Some scatter of the data among twenty one samples (including four duplicate pairs) from the Cacela River site is observed. The strontium isotope values range from 0.708879 to 0.709029 with that seven samples yielded ${ }^{87} \mathrm{Sr} /{ }^{86} \mathrm{Sr}$ values of $0.708928-0.708933$, and six other have ${ }^{87} \mathrm{Sr} /{ }^{86} \mathrm{Sr}$ values of $0.709961-0.708963$. Similar variability in ${ }^{87} \mathrm{Sr} /{ }^{86} \mathrm{Sr}$ values is observed in both calcite-built shell of Flabellipecten fraterculus (Sowerby) and aragonite shells of Peronaea planata (Linnaeus) and Clausinella fasciata (da Costa). As indicated in Table 3, the ${ }^{87} \mathrm{Sr} /{ }^{86} \mathrm{Sr}$ ratios of samples CAC $4 / 2$ and BS 04/2 were substantially lower whilst the ${ }^{87} \mathrm{Sr} /{ }^{86} \mathrm{Sr}$ ratio of sample CAC 6 was higher than of the others. This is the reason, why the mean value from the "most frequency area" was recognized as the most representative ${ }^{87} \mathrm{Sr} /{ }^{86} \mathrm{Sr}$ value for each dataset. The "most frequency area" means the range of ${ }^{87} \mathrm{Sr} /{ }^{86} \mathrm{Sr}$ values which includes a great number of measured values; values which were out of this range were rejected due to possible effect of sample material contamination or measuring errors. Uncertainty of mean values determination was given using the modified McArthur formula $2 \mathrm{se}_{\text {total }}=2 \sqrt{\left(\mathrm{se}_{1}^{2}+\left(1 / n \sum \mathrm{se}_{n}\right)^{2}\right)}$ where $\mathrm{se}_{1}$ is the standard error of mean value from dataset and $\mathrm{se}_{n}$ is the standard error of measuring ${ }^{87} \mathrm{Sr} /{ }^{86} \mathrm{Sr}$ ratio for each sample value (McArthur,
1994). Strontium isotope values of the CAC 4/2, CAC 6 and BS 04/2 samples were not included in age determination.

Lacem. - Six samples were examined. Four samples showed negligible differences in ${ }^{87} \mathrm{Sr} /{ }^{86} \mathrm{Sr}$ values $(0.708941-0.708949)$ whereas the ${ }^{87} \mathrm{Sr} /{ }^{86} \mathrm{Sr}$ values measured on the lucinid species Linga (Linga) columbella (Lamarck) and the venerid species Paphia aenigmatica (Fischer et Tournouër) have average values as much as 0.000015 lower. The ${ }^{87} \mathrm{Sr} /{ }^{86} \mathrm{Sr}$ values of both the calcite-shell of Flabellipecten fraterculus (Sowerby) and the aragonite shell of Cardium indicum Lamarck are equal to 0.708947 .

\section{AGE ESTIMATES}

The ${ }^{87} \mathrm{Sr} /{ }^{86} \mathrm{Sr}$ values of the samples have been converted to numerical age using the standard tables of McArthur et al. (2001) based on the refined Sr isotope curve for Neogene seawater and geological time scale of the International Chronostratigraphic Chart (2012). Figure 10 and Table 4 summarize the resulting ages for each fossiliferous site. The ${ }^{87} \mathrm{Sr} /{ }^{86} \mathrm{Sr}$ ratios measured in all forty two bivalve samples from the Cacela Formation range from 0.708926 to 0.709011 (Table 3 ) and a calculated age corresponds with the interval of $8.9 \pm$ $0.4 \mathrm{Ma}$ and $5.7 \pm 0.5 \mathrm{Ma}$ (late Tortonian-Messinian).

The stratigraphically lowest bivalve samples were collected at Lacem. From this locality, six samples were examined: two give a calculated age of $8.9 \pm 0.4 \mathrm{Ma}(\mathrm{LAC} 7)$ and $8.8 \pm 0.4 \mathrm{Ma}$ (LAC 9) and four suggest a calculated age of $7.8 \pm 0.4$ Ma to 7.2 $\pm 0.4 \mathrm{Ma}$. As far they represent the oldest marine bivalves in the Cacela Formation (Fig. 11). If this age assessment is correct (we examined only six samples) the bivalve fauna inhabited the Algarve Basin in the late Tortonian since at least c. $8.9 \pm 0.4 \mathrm{Ma}$.

Of the eighteen samples from the Cacela River site, seven samples (CAC 2, CAC 7, GZBS 6/A, BZBS 6/B, BS 5, BS 02/b, $\mathrm{BS} 02 / \mathrm{C}$ ) yield a calculated age of $8.8 \pm 0.3 \mathrm{Ma}$ to $8.6 \pm 0.4 \mathrm{Ma}$, 
Table of ${ }^{87} \mathrm{Sr} /{ }^{86} \mathrm{Sr}$ values (with $2 \sigma$ analytical error ranges)

\begin{tabular}{|c|c|c|c|c|}
\hline Locality & Sample & Species & ${ }^{87} \mathrm{Sr} /{ }^{86} \mathrm{Sr}$ & $2 \mathrm{se}$ \\
\hline \multirow{6}{*}{ Barroquinha } & BAR 7 & Flabellipecten fraterculus & 0.708944 & $2.10 \mathrm{E}-05$ \\
\hline & BS 8 & Flabellipecten fraterculus & 0.708970 & 2.10E-05 \\
\hline & BS 8 & Flabellipecten fraterculus & 0.708963 & $2.00 \mathrm{E}-05$ \\
\hline & BAR 9 & Talochlamys multistriata & 0.708976 & 2.00E-05 \\
\hline & BAR 11 & Flabellipecten fraterculus & 0.708944 & $2.40 \mathrm{E}-05$ \\
\hline & BAR 12 & Ostrea edulis & 0.709033 & 3.50E-05 \\
\hline \multirow{7}{*}{ Cabanas 1} & CAB 10 & Flabellipecten fraterculus & 0.708960 & $1.50 \mathrm{E}-05$ \\
\hline & CAB 11 & Flabellipecten fraterculus & 0.708948 & $1.50 \mathrm{E}-05$ \\
\hline & CAB 12 & Talochlamys multistriata & 0.708958 & $1.00 \mathrm{E}-05$ \\
\hline & CAB 15 & Flabellipecten fraterculus & 0.708980 & 2.00E-05 \\
\hline & GZBS 3 & Talochlamys multistriata & 0.708968 & $1.20 \mathrm{E}-05$ \\
\hline & GZBS 4 & Flabellipecten fraterculus & 0.708958 & 1.20E-05 \\
\hline & Cabanas PT & Talochlamys multistriata & 0.708968 & $1.20 \mathrm{E}-05$ \\
\hline \multirow{3}{*}{ Cabanas 2} & BS 13 & "Amussium" cristatum badense & 0.708980 & 1.00E-05 \\
\hline & CAB $14 / 2$ & "Amussium" cristatum badense & 0.709011 & $2.10 \mathrm{E}-05$ \\
\hline & CAB $14 / 1$ & "Amussium" cristatum badense & 0.709011 & $2.30 \mathrm{E}-05$ \\
\hline \multirow{21}{*}{ Cacela } & CAC 1 & Flabellipecten fraterculus & 0.708951 & 1.40E-05 \\
\hline & CAC 2 & Flabellipecten fraterculus & 0.708928 & 1.10E-05 \\
\hline & CAC 3 & Flabellipecten fraterculus & 0.708954 & $1.40 \mathrm{E}-05$ \\
\hline & $\mathrm{CAC} \mathrm{4/1}$ & Megacardita jouanneti & 0.708970 & 1.00E-05 \\
\hline & CAC $4 / 2$ & Megacardita jouanneti & 0.708879 & 2.70E-05 \\
\hline & CAC 5 & Saccella commutata & 0.708958 & $1.20 \mathrm{E}-05$ \\
\hline & CAC 6 & Anadara diluvii & 0.709029 & 1.20E-05 \\
\hline & CAC 7 & Paroxystele rotellaris & 0.708930 & 2.10E-05 \\
\hline & GZBS 6/A & Peronaea planata & 0.708929 & $1.20 \mathrm{E}-05$ \\
\hline & GZBS 6/B & Peronaea planata & 0.708928 & $1.20 \mathrm{E}-05$ \\
\hline & BS 04/1 & Peronaea planata & 0.708945 & $1.20 \mathrm{E}-05$ \\
\hline & BS $04 / 2$ & Peronaea planata & 0.708912 & 1.10E-05 \\
\hline & BS 4 & Peronaea planata & 0.708961 & 1.20E-05 \\
\hline & BS 5 & Peronaea planata & 0.708929 & $1.30 \mathrm{E}-05$ \\
\hline & BS 6 & Peronaea planata & 0.708963 & $1.30 \mathrm{E}-05$ \\
\hline & $\mathrm{BS} 02 / \mathrm{b}$ & Flabellipecten fraterculus & 0.708933 & 9.00E-05 \\
\hline & BS 02/c & Flabellipecten fraterculus & 0.708930 & 1.00E-05 \\
\hline & GZBS 5/1 & Clausinella fasciata & 0.708951 & $1.50 \mathrm{E}-05$ \\
\hline & GZBS 5/2 & Clausinella fasciata & 0.708945 & 1.50E-05 \\
\hline & BS 03/1 & Clausinella fasciata & 0.708963 & $1.00 \mathrm{E}-05$ \\
\hline & BS $03 / 2$ & Clausinella fasciata & 0.708965 & 9.00E-05 \\
\hline \multirow{6}{*}{ Lacem } & LAC 4 & Flabellipecten fraterculus & 0.708947 & 1.40E-05 \\
\hline & LAC 5 & Clausinella fasciata & 0.708941 & 1.90E-05 \\
\hline & LAC 6 & Cardium indicum & 0.708947 & 6.10E-05 \\
\hline & LAC 7 & Paphia aenigmatica & 0.708926 & $2.20 \mathrm{E}-05$ \\
\hline & LAC 8 & Acanthocardia paucicostata & 0.708949 & $1.60 \mathrm{E}-05$ \\
\hline & LAC 9 & Linga (Linga) columbella & 0.708928 & $1.60 \mathrm{E}-05$ \\
\hline Slovakia & IL Standard & Ervilia podolica & 0.708588 & 1.80E-05 \\
\hline
\end{tabular}




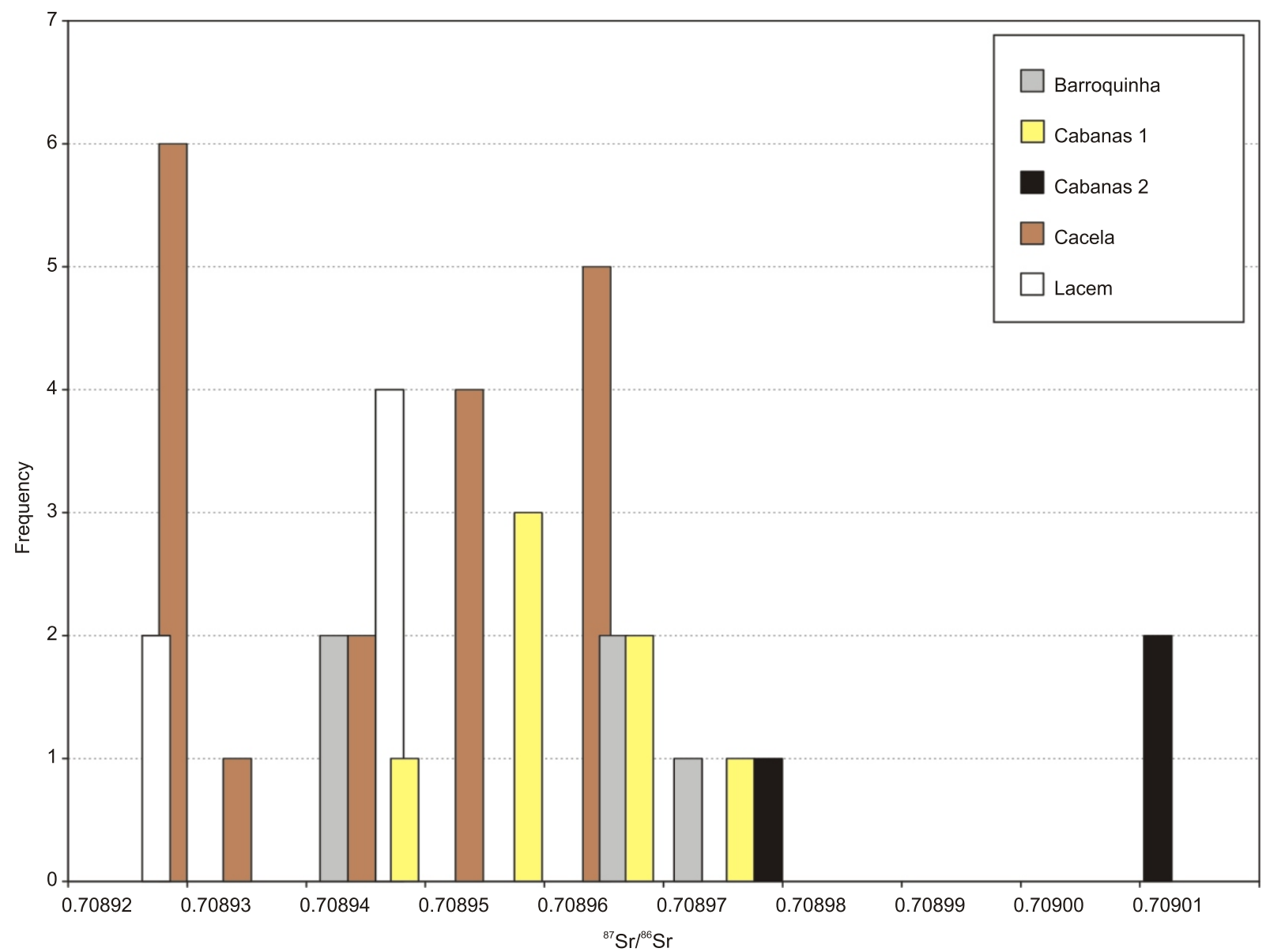

Fig. 9. Frequency distribution diagram of ${ }^{87} \mathrm{Sr} /{ }^{86} \mathrm{Sr}$ values content in bivalve shells from the studied fossiliferous sites

Results of estimated ages for all localities, based on mean values from each ${ }^{87} \mathrm{Sr}^{88} \mathrm{Sr}$ ratio dataset

\begin{tabular}{|l|c|c|c|c|}
\hline \multicolumn{1}{|c|}{ Locality } & ${ }^{87} \mathrm{Sr} /{ }^{86} \mathrm{Sr}$ mean value & 2se & $\begin{array}{c}\text { SIS age } \\
{[\mathrm{Ma}]}\end{array}$ & $\begin{array}{c}\text { Error } \\
{[ \pm \mathrm{Ma}]}\end{array}$ \\
\hline Barroquinha & 0.708959 & $2.10 \mathrm{E}-05$ & 7.0 & 0.5 \\
\hline Cabanas 1 & 0.708963 & $1.40 \mathrm{E}-05$ & 6.7 & 0.4 \\
\hline Cabanas 2 & 0.709001 & $1.80 \mathrm{E}-05$ & 5.9 & 0.5 \\
\hline Cacela & 0,708946 & $2.10 \mathrm{E}-05$ & 7.6 & 0.4 \\
\hline Lacem & 0.708939 & $2.50 \mathrm{E}-05$ & 7.9 & 0.5 \\
\hline
\end{tabular}

five samples (CAC 1, CAC 3, BS 94/1, GZBS 5/1, GZBS 5/2) have a calculated age of $7.7 \pm 0.3 \mathrm{Ma}$ to $7.0 \pm 0.4 \mathrm{Ma}$ whereas six samples (CAC 4/1, CAC 5, BS 4, BS 6, BS 03/1, BS 03/2) suggest a younger calculated age around $6.6 \pm 0.4 \mathrm{Ma}$. The estimated age based on the ${ }^{87} \mathrm{Sr} /{ }^{86} \mathrm{Sr}$ ratio in bivalve shell samples from the Cacela River is defined as late Tortonian $(7.6 \pm 0.4 \mathrm{Ma})$ and is in agreement with previous biostratigraphic studies based on calcareous nannofossil and planktonic foraminifers (Cachão, 1995a; Legoinha, 2003; respectively).

The strontium isotopic analysis of bivalve shells from Barroquinha suggests an age around the Tortonian/Messinian boundary. Of the five samples examined from this site, two (BAR 11 and BAR 7) yield a calculated age around 7.5 $\pm 0.4 \mathrm{Ma}$, and three suggest a younger calculated age of $6.75 \pm 0.4 \mathrm{Ma}$ (BS 8) and 6.4 $\pm 0.5 \mathrm{Ma}$ (BAR 9).
The stratigraphically youngest bivalve samples were collected at Cabanas. From this locality, 10 samples were examined; the samples from Unit B have a calculated age between $7.3 \pm 0.4 \mathrm{Ma}$ and $6.3 \pm 0.5 \mathrm{Ma}$, whilst the three samples from overlying Unit $D$ give a calculated age between $6.3 \pm 0.4 \mathrm{Ma}$ (BS 13) and $5.7 \pm 0.5 \mathrm{Ma}(\mathrm{CAB} 14)$. Based on ${ }^{87} \mathrm{Sr} /{ }^{86} \mathrm{Sr}$ ratios in the low-Mg calcite shells of scallops from Cabanas, the Messinian age of the bivalve fauna has been defined for the first time in Portugal. Thus, the results obtained from ${ }^{87} \mathrm{Sr} /{ }^{86} \mathrm{Sr}$ ratios in bivalve shells clearly indicate that the fauna from Cabanas is as young as Messinian $(6.7 \pm 0.4 \mathrm{Ma})$ and it is younger than the bivalves from the lower part of the Cacela River sequence defined as late Tortonian (7.6 $\pm 0.4 \mathrm{Ma})$. 

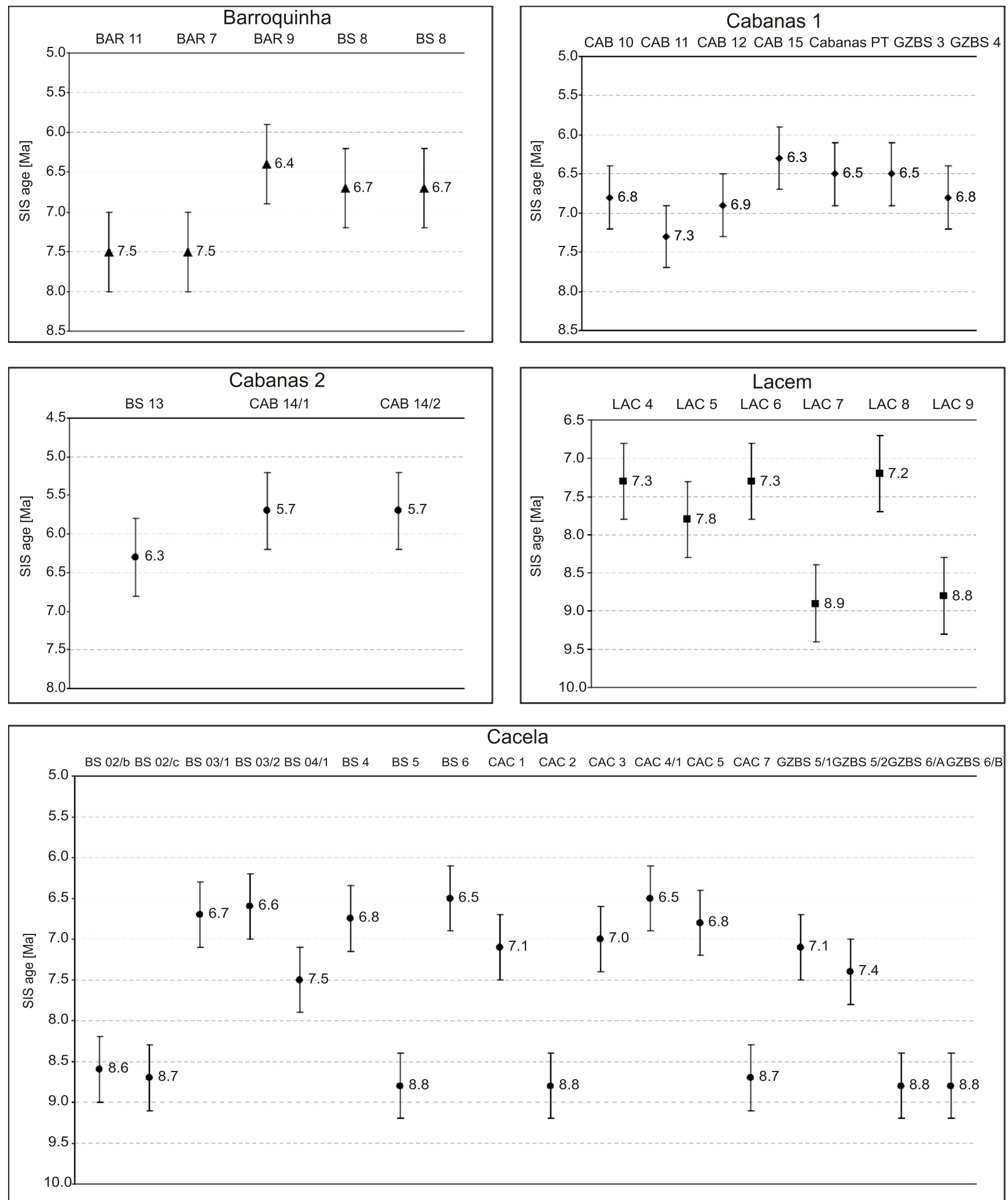

Fig. 10. Calculated age of bivalve samples from the studied Portuguese sites

See Table 3 for sample abbreviations 


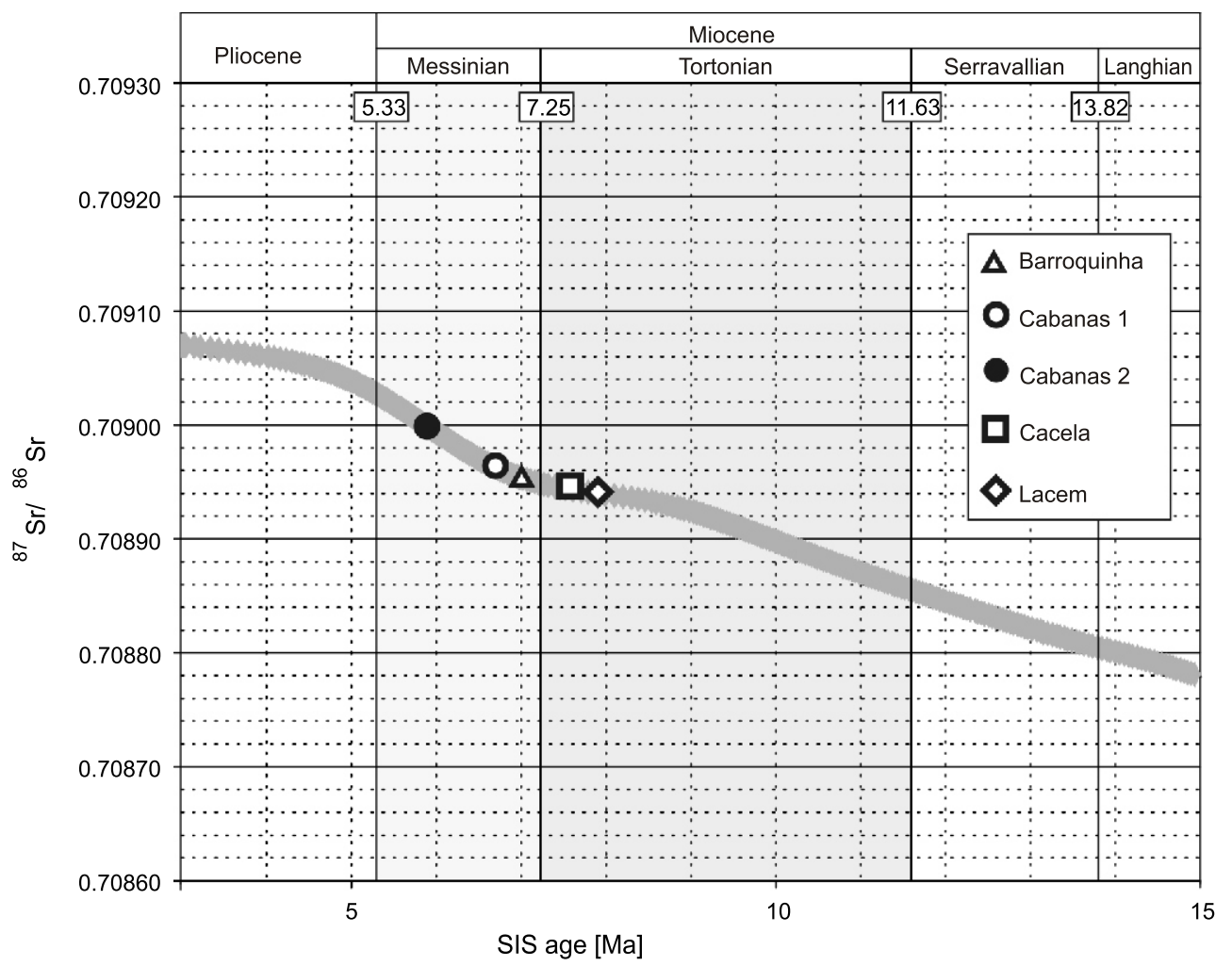

Fig. 11. Composite Miocene seawater ${ }^{87} \mathrm{Sr} /{ }^{86} \mathrm{Sr}$ reference curve from Howarth and McArthur (1997) and corresponding age of molluscan shells from the studied Portuguese sites

Chronology of the Miocene stage boundaries after the International Chronostratigraphic Chart 2012

\section{BIVALVES FROM THE CACELA FORMATION}

PREVIOUS STUDIES

Much of our knowledge of the bivalve fauna from the Cacela Formation comes from the monographic works of the last century given by Dollfus et al. (1903) and Chavan (1940). The basis for the former was the collection acquired by C. Ribeiro and J.F. Nery Delgado near the village of Cacela Velha in the 1860s and studied by F.A. Pereira da Costa. Several series of outstanding plates have been prepared under Pereira da Costa's supervision, presenting beautiful, scientifically accurate drawings of Portuguese Tertiary molluscs, items representing gastropods appeared in the publications of the Sciences Academy of Lisbon (1866-1867). The remaining ones, representing mainly bivalves, were published by Dollfus et al. (1903), who had updated all the illustrated material. Three bivalve plates (numbered III, V and $\mathrm{VI}$ ) have been lost. A total of 55 bivalve species were recognized by Dollfus et al. (1903) within the fossil material derived from various Portuguese Miocene localities, including 47 species from the vicinity of Cacela Velha, 44 of which were illustrated. The representatives of the family Pectinidae were missing among them. They were illustrated and included by Veiga Ferreira (1951) in his monograph on the scallops from the Miocene of Algarve.

The precise location of the illustrated bivalves was not mentioned by Pereira da Costa, but according to Berkeley Cotter (1904: p. 40), they were derived mainly from the unit of $3.0 \mathrm{~m}$ thick yellowish and greyish fine-grained micaceous sand cropping out on the right bank of the Cacela River (downstream from the bridge) about $1000 \mathrm{~m}$ NNE of the local church. The Berkeley Cotter's (1904) brief paper, summarizing knowledge of Portuguese Miocene deposits, contains a preliminary checklist of the bivalves from Cacela Velha. The same list of bivalve species was provided by Choffat (1950). The Miocene at the Cacela River was considered as Tortonian (Dollfus et al., 1903; Berkeley Cotter, 1904; Cossmann and Peyrot, 1909-1912; Bourcart and Zbyszewski, 1940; Freneix, 1957; Zbyszewski, 1957).

Other important geological and palaeontological publications dealing with the molluscan fauna from the Cacela Formation include those by Bourcart and Zbyszewski (1940), Chavan (1940, 1944) and Glibert and Van de Poel (1965-1970). From the fossiliferous-bearing strata at Monte Alto, $2 \mathrm{~km}$ E of Cacela Velha, Chavan (1940) documented 27 bivalve species and revized some determinations given by Dollfus et al. (1903). Based on the similarity with the bivalve fauna from Dar-bel-Amri in Morocco and on available knowledge on stratigraphic distribution of the carditid subspecies Megacardita jouanneti laeviplana (Depéret), Chavan regarded the Portuguese fauna as Sahelian, younger than Tortonian. Subsequently, Glibert and Van de Poel (1965-1970) referred some bivalve species from the Cacela River (collected in the beginning of the 20th century by Dollfus and deposited at the Royal Belgian Institute of Natural Sciences) to the so-called Sahelian based on the presumed occurrence of Megacardita jouanneti laeviplana, while other species derived in the same locality were regarded as Tortonian. Recent investigation has shown that the bivalve fauna from Dar-bel-Amri is probably early Zanclean (Early Pliocene), within the biozone of Globorotalia margaritae (Gonzales Delgado et al., 1995). 
More recently, a new collection from the Cacela River site (located c. 300 m upstream from the historical site at "Ribeira de Cacela") was completed by A. Santos during the 1990s. That material served as a basis for her Master's thesis and included 86 bivalve species (Santos, 2000). A preliminary checklist of bivalves sampled from the lower member of the Cacela Formation was published by Santos and Boski (1998), while relevant palaeoenvironmental and palaeoecological analyses were performed by Santos and Mayoral (2007). In addition, quantitative taphonomic analysis based on all molluscan fauna from the Cacela River site has been made by Rico-Garcia et al. (2006). Based on calcareous nannofossils (Cachão, 1995a) and planktonic foraminifers (Lagoinha, 2003), the age of the bivalves is determined as late Tortonian.

\section{COLLECTION HOUSED AT THE GEOLOGICAL MUSEUM IN LISBON}

The study of the material housed at the Geological Museum in Lisbon by the senior author has shown that the collection com- pleted in the 19th century by C. Ribeiro and J.F. Nery Delgado near Cacela Velha was supplemented with an extensive new collection gathered in the early 20th century by the staff of the Geological Survey of Portugal. Unfortunately, no comprehensive, systematic review of this material has been published. Only four scallop species were discussed by Veiga Ferreira (1951) and a new venerid species Paphia (Paphia) zbyszewskii was established by Freneix (1957). Current re-examination and revision revealed that the bivalve fauna is more diversified than it was expected from the two monographic works by Dollfus et al. (1903) and Chavan (1940). Ninety two bivalve species have been identified within the material taken from both the type section of the Cacela Formation and several other sites (e.g., Altar, near the village of Conceição de Tavira, Monte Pessõa and Ribeiro Alfonso Martins near the village of Cacela Velha). Although this bivalve fauna was discovered here in 1908, its content remained almost unknown until recently. Only two scallop species Flabellipecten fraterculus (Sowerby) and "Amussium" cristatum badense (Fontannes) were described and illustrated

Late Miocene bivalves gathered in 1908 by Berkeley Cotter at Altar near Conceição de Tavira village which are stored at the Geological Museum in Lisbon, Portugal

\begin{tabular}{|c|c|}
\hline Family & Species \\
\hline \multirow{3}{*}{ Nuculidae Gray, 1824} & Nucula (Nucula) nucleus (Linnaeus, 1758) \\
\hline & Nucula (Nucula) nitidosa Winckworth, 1930 \\
\hline & Nucula (Lamellinucula) jeffreysi Bellardi, 1875 \\
\hline \multirow{2}{*}{ Arcidae Lamarck, 1809} & Barbatia mytiloides (Brocchi, 1814) \\
\hline & Barbatia subhelbingi (d'Orbigny, 1852) \\
\hline Glycymerididae Newton, 1922 & Glycymeris (Glycymeris) nummaria (Linnaeus, 1758) \\
\hline \multirow{2}{*}{ Pectinidae Wilkes, 1810} & "Amussium" cristatum badense (Fontannes, 1882) \\
\hline & Flabellipecten fraterculus (Sowerby in Smith, 1847) \\
\hline Gryphaeidae Vyalov, 1936 & Hyotissa hyotis (Linnaeus, 1758) \\
\hline \multirow{3}{*}{ Lucinidae Fleming, 1828} & Lucina (Lucina) callipteryx (Tournouër, 1872) \\
\hline & Megaxinus transversus (Bronn, 1831) \\
\hline & Lucinoma borealis (Linnaeus, 1758) \\
\hline Carditidae Fleming, 1828 & Megacardita jouanneti (Basterot, 1825) \\
\hline \multirow{3}{*}{ Cardidae Lamarck, 1809} & Cardium indicum Lamarck, 1819 \\
\hline & Laevicardium crassum (Gmelin, 1791) \\
\hline & Acanthocardia paucicosta (G.B. Sowerby II, 1834) \\
\hline \multirow{3}{*}{ Mactridae Lamarck, 1809} & Lutraria (Lutraria) Iutraria (Linnaeus, 1758) \\
\hline & 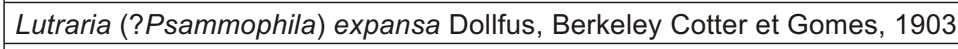 \\
\hline & Lutraria (Psammophila) oblonga (Gmelin, 1791) \\
\hline \multirow{5}{*}{ Tellinidae de Blainville, 1814} & Tellina (Oudardia) compressa (Brocchi, 1814) \\
\hline & Tellina (Tellinella) distorta (Poli, 1791) \\
\hline & \begin{tabular}{|l} 
Pharaonella pulchella (Lamarck, 1818) \\
\end{tabular} \\
\hline & Serratina serrata (Brocchi, 1814) \\
\hline & Macoma (Psammacoma) elliptica (Brocchi, 1814) \\
\hline \multirow{2}{*}{ Psammobiidae Fleming, 1828} & Gari fervensis (Gmelin, 1791) \\
\hline & Gari uniradiata (Brocchi, 1814) \\
\hline \multirow{2}{*}{ Solecurtidae d'Orbigny, 1846} & Solecurtus canditus (Brocchi, 1814) \\
\hline & Solecurtus basteroti (DesMoulins, 1832) \\
\hline \multirow{8}{*}{ Veneridae Rafinesque, 1815} & Venus (Ventricoloidea) nux (Gmelin, 1791) \\
\hline & Circomphalus foliaceolamellosus (Dillwyn, 1817) \\
\hline & Callista (Costacallista) erycinoides (Lamarck, 1806) \\
\hline & Callista (Macrocallista) italica (Defrance, 1818) \\
\hline & \begin{tabular}{|l} 
Pelecyora (Cordiopsis) brocchii (Deshayes, 1836) \\
\end{tabular} \\
\hline & Callistotapes vetula (Basterot, 1825) \\
\hline & Callistotapes aenigmatica (Fischer et Tournouër, 1874) \\
\hline & Clausinella basteroti (Deshayes, 1850) \\
\hline Cuspidariidae Dall, 1866 & Cuspidaria rostrata (Spengler, 1793) \\
\hline
\end{tabular}


by Veiga Ferreira (1951) from Altar, near the village of Conceição de Tavira. The list of the bivalve species from this locality, preserved at the Geological Museum in Lisbon, with their current identifications is given in Table 5. This bivalve assemblage comprises 37 species that represent 30 genera of 14 families. Neither calcareous nannoplankton nor planktonic foraminifera were studied to clarify the stratigraphic position of the Cacela Formation in this locality (cf. Pais et al., 2012), thus its age remains uncertain.

Examination of the material from the historical site of "Ribeira de Cacela", stored in Lisbon, adds valuable information concerning its taxonomic content (only part of the material was illustrated by Dollfus et al., 1903) and the state of bivalve shell preservation. It is noteworthy that it resembles closely Unit A at Lacem - in both lithology and bivalve content. The two units are predominantly unconsolidated greyish-brownish micaceous fine to very fine unstratified silty sands and clays (cf. Berkely Cotter, 1904) with well-preserved robust articulated and disarticulated aragonite valves of Glycymeris (Glycymeris) bimaculata (Poli), Megacardita jouanneti (Basterot), Discors spondyloides (Von Hauer), Pelecyora (Cordiopsis) gigas (Lamarck) and Callista (Callista) aff. gauderndorfensis Schaffer. Therefore, one can reasonably suppose that the bivalves from the historical site of "Ribeira de Cacela" are contemporaneous with the bivalves from the Lacem site (Unit A).

\section{A NEW MESSINIAN BIVALVE FAUNA}

A unique collection was gathered from Unit B at Cabanas. The specimens are generally poorly preserved and the shell material is mostly dissolved (Figs. 2A, B, 4B-G); only oysters and scallops are well-preserved. The latter are represented by five species: "Amussium" cristatum badense (Fontannes), Pecten subarcuatus Tournouër, Flabellipecten fraterculus (Sowerby), Talochlamys multistriata (Poli) and Aequipecten seniensis (Lamarck) but only Flabellipecten fraterculus and Talochlamys multistriata (Poli) are common. Small-sized $(1-2 \mathrm{~cm})$ articulated shells of these two scallop species occur throughout the unit, whereas oysters become more common towards the top. Sporadically, in the upper part, small clusters of oyster Ostrea edulis Linnaeus were found ( 2 or 3 articulated shells). The aragonitic shells, being partly dissolved, are preserved mostly as slightly disrupted external or composite moulds. In some cases, however, details of the external delicate ornamentation such as spines on Acanthocardia paucicostata (Sowerby) are observed. Great number of individuals of Acanthocardia paucicostata, the dominant species in the assemblage, as well as Pelecyora (Cordiopsis) brocchii (Deshayes), Paphia zbyszewskii Freneix and Lutraria (Lutraria) lutraria (Linnaeus) or even Cardium indicum Lamarck were articulated before burial (Fig. 4E-G). The very high percentage of articulated shells, the wide range of modal size values of fossil species and many specimens preserved in their life position indicate minimum post-mortem alteration.

Within the collected material, 60 bivalve species belong to 22 families of which the family Veneridae is characterized by particularly high taxonomic diversity (Table 1). The present research provides the first occurrence of Pseudopythina macandrewi $(\mathrm{P}$. Fischer), Coripia corbis (Philippi), Glossus humanus (Linnaeus) and Cyathodonta dollfusi (Cossmann et Peyrot) in the Miocene of southern Portugal. Based on literature (Cossmann and Peyrot, 1909-1912; Dollfus and Berkeley Cotter, 1909; Schaffer, 1910; Zbyszewski, 1957; Glibert and Van de Poel, 1965-1970; Malatesta, 1963; Tavani and Tongiorgi, 1963; Tebble, 1966; Studencka and Studencki, 1988; Ben Mussa, 1994; Calzada, 1995; Pfister and Wegmüller, 2001; Schultz,
2005), data on the stratigraphic range and geographic distribution of these species are briefly presented below.

Pseudopythina macandrewi (P. Fischer). - This extremely rare species is restricted to the Atlantic Province. Up to now, it has been known exclusively from the Lower Pliocene (Piacenzian) at Aquas santos and Nadadoiro in the Lower Tagus Basin, Portugal (Dollfus and Berkeley Cotter, 1909). The present-day Pseudopythina macandrewi is also scarcely distributed along the Atlantic coast of Spain and Portugal. It seems that the Algarvian record is the oldest evidence of this species.

Coripia corbis (Philippi). - The species is known throughout the Atlantic and Mediterranean provinces in the Miocene and Pliocene. Its occurrence in the Pleistocene has been confirmed in the Mediterranean (Malatesta, 1963). The present-day Coripia corbis is scarcely distributed in the Atlantic Ocean: its living specimens were found only along the Atlantic coast of Morocco (Ben Moussa, 1994).

Glossus (Glossus) humanus (Linnaeus) (Fig. 4A). - The earliest certain record of Glossus (G.) humanus (known as Isocardia cor in older literature) is from the Middle Miocene of the Paratethys (Studencka and Studencki, 1988). Its occurrence in both the Atlantic and Mediterranean provinces is known at least since the Late Miocene (see records and bibliography in Schultz, 2005). The modern Glossus (G.) humanus is distributed over the North Atlantic from Iceland and Norway to Morocco, and into the Mediterranean and Adriatic seas (Tebble, 1966).

Cyathodonta dollfusi (Cossmann et Peyrot) (Fig. 4B-D). The species was previously reported from the Lower Miocene (Burdigalian) of the Atlantic and Paratethyan provinces. Its occurrence in the Atlantic Province was documented in the Aquitaine Basin, France (Cossmann and Peyrot, 1909; Glibert and Van de Poel, 1966) and in the Lower Tagus Basin, Portugal (Zbyszewski, 1957). In the Paratethys, it was found in the Upper Marine Molasse (middle Burdigalian) in Switzerland (Pfister and Wegmüller, 2001). The species Cyathodonta dollfussi was not common in the Miocene Mediterranean Province. It was only known from the Middle Miocene (Langhian) of Catalan localities, Spain (Calzada, 1995). The shell of Cyathodonta dollfussi ornamented with concentric and moderately prominent rolles, alternating with slightly narrower and flat grooves resembles closely those described as Thracia eggenburgensis by Schaffer (1910) from the Lower Miocene (Eggenburgian) in Austria. The only differences are slightly shorter posterior part of shell and more distinct concentric ornamentation. Therefore, it is likely that Cyathodonta eggenburgensis (Schaffer) reported from the Lower Miocene (Eggenburgian) of southern Slovakia (Schultz, 2005), Switzerland (Pfister and Wegmüller, 2001), Middle Miocene (Lower Badenian) of Poland (Studencka and Studencki, 1988) and from the Upper Miocene (Tortonian) of Italy (Tavani and Tongiorgi, 1963) represents a morphotype of Cyathodonta dollfusi.

\section{BIVALVES FROM CABANAS COMPARED TO THOSE FROM THE CACELA RIVER}

Cachão (1995a), and Cachão and Silva (2002) claimed that the age of molluscan fauna from the Cabanas section and that of the Cacela River was the same. The results obtained from ${ }^{87} \mathrm{Sr}{ }^{86} \mathrm{Sr}$ ratios in bivalve shells from Cabanas (10 scallop shell samples) and the Cacela River (21 bivalve shell samples) have unequivocally evidenced that the bivalve fauna from Cabanas is as young as Messinian and it is younger than the bivalves from the Cacela River (Fig. 11). Both the strontium isotope analysis (this study) and biostratigraphic data (Cachão, 1995a; Lagoinha, 2003) suggest that the bivalve fauna from the lower part of the 


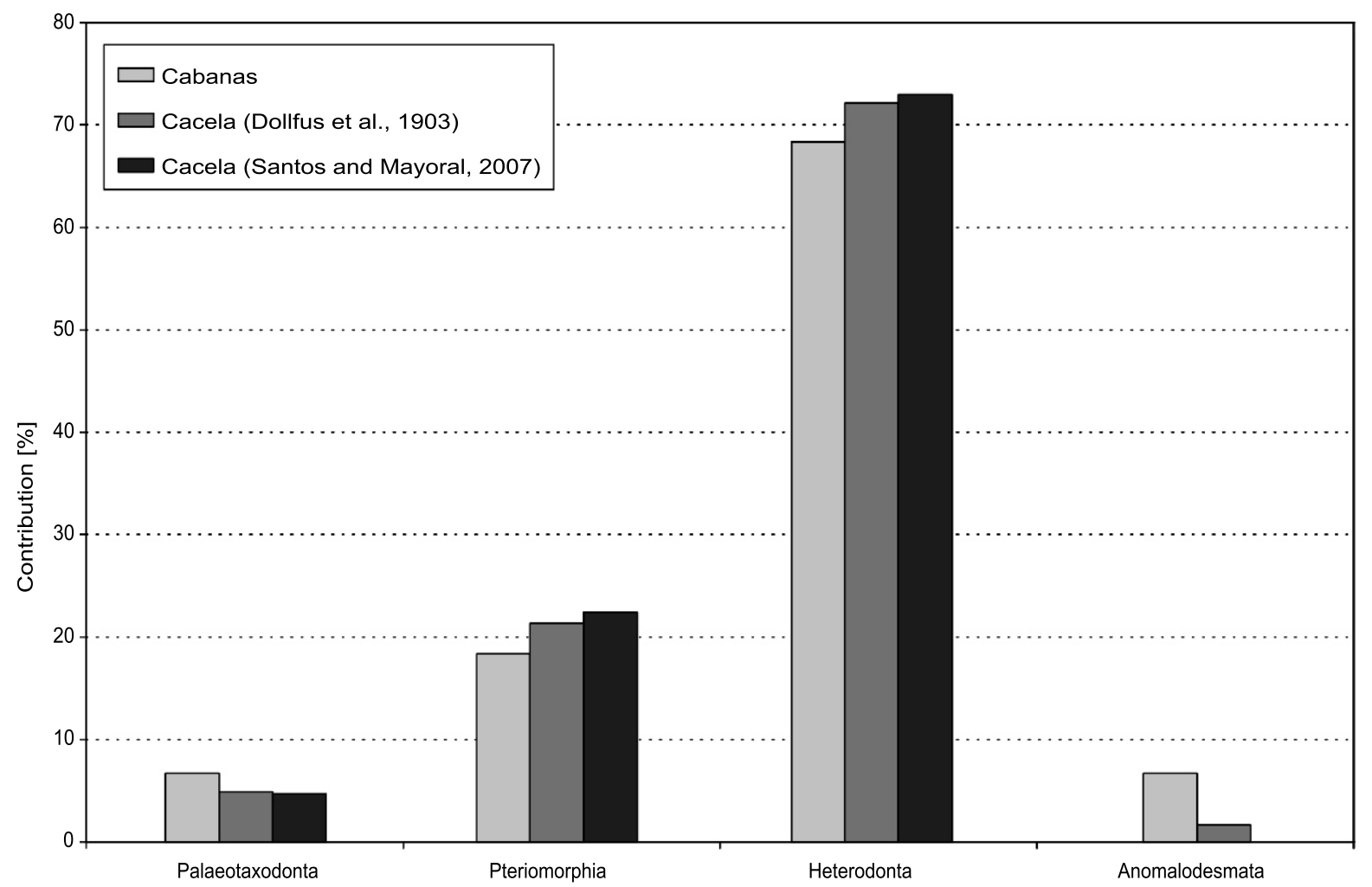

Fig. 12. Percentages of major taxonomic bivalve groups in fauna derived from the Cacela Formation at Cabanas (this study) and in the Cacela River sites (Dollfus et al., 1903; Santos and Mayoral, 2007)

Cacela River section discussed by Gonzáles Delgado et al. (1995), Santos and Boski (1998), Santos (2000), and Santos and Mayoral (2007) is late Tortonian in age.

On the other hand it is difficult to separate the late Tortonian and the early Messinian bivalve faunas from Algarve (Santos and Mayorol, 2007: table 2; Table 1) because of similarities in the taxonomic composition of the assemblages in the two time slices. Moreover, the taxonomic structure expressed in percentages of particular bivalve subclasses in assemblages under comparison is nearly the same (Fig. 12). The Veneridae (11 species in Cabanas; 15 species in the Cacela River), Tellinidae (6; $10)$, Lucinidae $(6 ; 5)$, Pectinidae $(5 ; 7)$ and Cardiidae $(4 ; 7)$ contribute to both Tortonian and Messinian faunas rather uniformly, being characterized by the highest species richness value. They comprise more than one third of all recorded species (Fig. 13). The representatives of the family Pectinidae considered to be significant in the stratigraphic division of Neogene deposits (see e.g., Ben Moussa and Demarcq, 1993; Ben Moussa, 1994) are not indicative of the Tortonian and Messinian stages (comp. Lauriat-Rage et al., 1999; Lacour et al., 2002). Neither species is currently documented solely from the Messinian or Tortonian of the Northeastern Atlantic. The species Flabellipecten fraterculus (Sowerby) occurred abundantly during the Tortonian within the Atlantic and Mediterranean provinces. It is also very common in the Messinian fauna from Cabanas, the Southern Rifian Basin in Morocco (Lauriat-Rage et al., 1999) and the Sorbas Basin in southern Spain (Lacour et al., 2002). Our results, therefore, support the opinion by Lauriat-Rage et al. (1993) that neither major faunal nor nannoplankton change apparently occurred between the Tortonian and Messinian.

The importance hierarchy for other families differs in the Cacela River and Cabanas faunas (Fig. 13). It may be caused by different environmental conditions. The presence of Glycymeridae and Isognomidae is characteristic for the Cacela River fauna. Large bivalves, particularly thick-shelled Glycymeris (Glycymeris) bimaculata (Poli), Isognomom (Hippochaeta) maxillatus (Lamarck) as well as Megacardita jouanneti (Deperet), Callista italica (Linnaeus) and Pelecyora (Cordiopsis) gigas (Lamarck) are good evidence for a shallow-water environment. In turn, indicators for deeper water conditions, such as Cuspidaridae and Thracidae, are most conspicuous in the Messinian fauna from Cabanas. According to Santos and Mayoral (2007), the bivalves found at the Cacela River, bioerosion structures and facies development are indicative of a nearshore environment with low to moderate hydrodynamic conditions and depths around 20 to 30 metres. Thus, the absence of Glycymeridae, Isognomidae and Veneridae with large and massive shells in the Cabanas fauna as well as the presence of Cuspidaridae, Thracidae and Cardiidae with fragile shells have been here interpreted as representative to the littoral zone but deeper than in the Cacela River. 


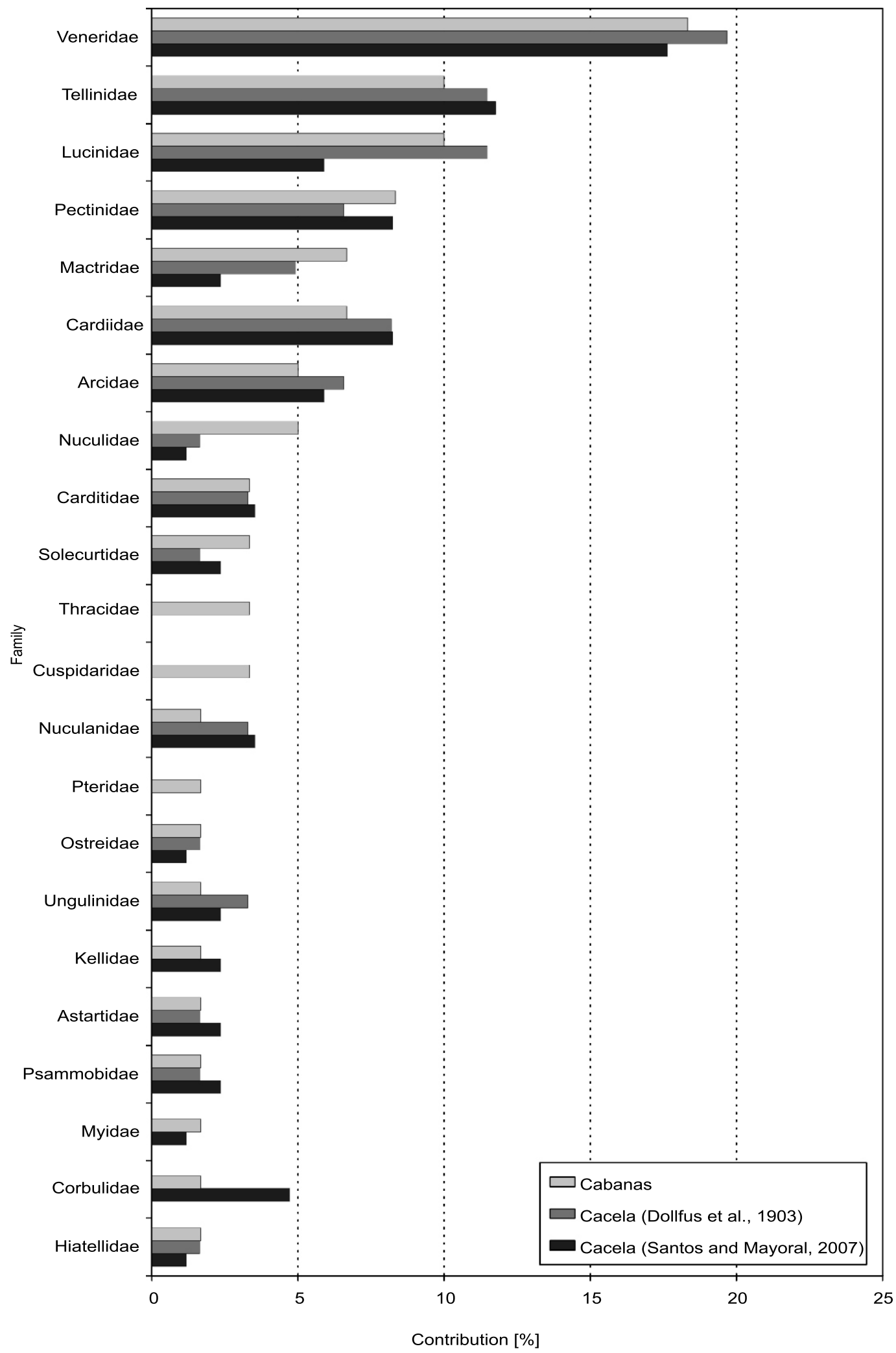

Fig. 13. Frequency distribution diagram of bivalve families from Cabanas (this study) and the Cacela River sites (Dollfus et al., 1903; Santos and Mayoral, 2007) 


\section{CONCLUSIONS}

Several isolated occurrences of the Cacela Formation in the eastern Algarve region have yielded a diverse molluscan fauna. The precise stratigraphic position of majority of these fossil-bearing strata remains uncertain: they hardly contain planktonic foraminifera, just sparse nannofossils. Only the lower part of the Cacela River sequence that yields the molluscan fauna of highest species diversity and unique, excellent shell preservation have been dated using calcareous nannoplankton and planktonic foraminifera and determined as latest Tortonian.

The study demonstrates the clear potential for the ${ }^{87} \mathrm{Sr} /{ }^{86} \mathrm{Sr}$ isotopic analyses to provide independent age information for the Cacela Formation. The ${ }^{87} \mathrm{Sr} /{ }^{86} \mathrm{Sr}$ ratios found in bivalve samples from four fossiliferous sites range from 0.708926 to 0.709011 and their calculated age ranges from $8.9 \pm 0.4 \mathrm{Ma}$ to $5.7 \pm 0.5 \mathrm{Ma}$ (late Tortonian-early Messinian). The oldest bivalves from the Cacela Formation are found in Lacem. Eight ${ }^{87} \mathrm{Sr} /{ }^{86} \mathrm{Sr}$ dates from the bivalve shells point to an age of about $8.9 \pm 0.4 \mathrm{Ma}$ (late Tortonian). The geological age of bivalve fauna from the Cacela River site is defined as the latest Tortonian, which is in agreement with biostratigraphic data. The Barroquinha data indicate an age range corresponding to the Tortonian/Messinian boundary. Finally, based on the ratio of two isotopes of strontium (ranging from 0.708948 to 0.708980 ) in scallop shells from Cabanas, the Messinian age has been defined. This means the first occurrence of Messinian bivalves in Portugal.

The Portuguese Messinian fauna resembles the Tortonian fauna in both taxonomic composition and structure. The Messinian marine mollusc records along the Eastern Atlantic and Mediterranean coasts are scant, discontinuous and often difficult to date (cf. Lauriat-Rage et al., 1993, 1999; Lacour et al., 2002; Monegatti and Raffi, 2007). With these new data, the Cacela Formation appears one of the few well-dated Eastern Atlantic macro-fossiliferous outcrops of the Late Miocene and offers the opportunity to better understand the relations between the Atlanic Messinian shallow-water molluscan fauna and that of the Mediterranean.

Acknowledgments. The senior author expresses warm and sincere thanks to Dr. A. Santos (University of Huelva, Spain) for her generosity and assistance in the fieldwork, for making accessible her unpublished M.Sc. thesis and collection from the Cacela River as well as for providing bivalve shells for the strontium isotope analysis. The assistance in the fieldwork and logistic support provided by CIMA, University of Algarve in Faro, Portugal, and Prof. T. Boski in particular, are gratefully acknowledged. Prof. M. Ramalho and Dr. J.M. Brandão (Geological Museum in Lisbon, Portugal) have kindly given access to the entire, not yet formally labelled, historical collection from the vicinity of Cacela. The senior author benefited considerably from fruitful discussion with Dr. M. Cachão and Dr. C. da Silva (University of Lisbon) concerning stratigraphic issues of the Neogene of Algarve and Portugal as a whole, from common fieldwork and from the data presented in Dr. M. Cachão's unpublished Ph.D. thesis. Both authors are much indebted to D. Nast MSc (Museum of the Earth in Warsaw) who has taken the photographs. Two anonymous reviewers have kindly offered some suggestions to clarify the content of this paper. Financial support for the work in Portugal was provided through the EC Marie Curie Fellowship grant MCFI-2001-00100 to B. Studencka.

\section{REFERENCES}

Antunes M.T, Pais J. (1992) The Neogene and Quaternary of Algarve. Excursion C (Portuguese part). Ciências da Terra (UNL), Numero especial, II: 57-66.

Antunes M.T, Bizon G., Nescimento A., Pais J. (1981) Nouvelles données sur la datation des dépôts miocènes de l'Argarve (Portugal) et l'évolution géologique régionale. Ciências da Terra (UNL), 6: 153-168.

Antunes M.T, Civis J., Dabrio C.J., Sierro F.J., Glez-Delgado J.A., Pais J., Valle M. (1990) El Neogeno del Algarve (Portugal) y de la cuenca del Guadalquivir (España). Actas de Paleontología, 68: 65-73.

Backman J., Raffi I., Rio D., Fornaciari E., Pälike H. (2012) Biozonation and biochronology of Miocene through Pleistocene calcareous nannofossils from low and middle latitudes. Newsletters on Stratigraphy, 45 (3): 221-244.

Bailey T.R., McArthur J.M., Prince H., Thirlwall M.F. (2000) Dissolution methods for Strontium Isotope Stratigraphy: whole rock analysis. Chemical Geology, 167: 313-319.

Ben Moussa A. (1994) Les bivalves néogènes du Maroc septentrional (façades Atlanitique et Méditerranéenne). Biostratigraphie, paléobiogéographie et paléoécologie. Documents des Laboratoires de Géologie Lyon, 132: 3-281.

Ben Moussa A., Demarcq G. (1993) Temporal and spatial distribution of Neogene pectinids communities in W. Mediterranean. Paleontologia i Evolució, 24-25: 175-183.

Betzler C., Braga J.C., Martin J.M., Sánchez-Almazo I.M., Lindhorst S. (2006) Closure of a seway: stratigraphic record and facies (Guadix basin, Southern Spain). International Journal of Earth Sciences (Geologische Rundschau), 95: 903-910.
Berkeley Cotter J.C. (1904) Esquisse du Miocene marin portugais. Algarve. In: Mollusqes Tertiaires du Portugal (eds. G.F. Dollfus, J.C.Berkeley Cotter and J.P. Gomez, 1903-1904): 39-44. Academia real das sciencias. Lisbonne.

Berggren W.A., Kent D.V., Swisher C.C. III, Aubry M. (1995) A revised Cenozoic geochronology and chronostratigraphy. SEPM Special Publication, 54: 129-212.

Bourcart J., Zbyszewski G. (1940) La faune de Cacela en Algarve (Portugal). Comunicação dos Serviços Geológicos du Portugal, 21: 3-60.

Brand U. (1991) Strontium isotope diagenesis of biogenic aragonite and low-Mg calcite. Geochimica et Cosmochimica Acta, 22: 505-513.

Brand U., Veizer J. (1980) Chemical diagenesis of multicomponent carbonate system -1 . Trace elements. Journal of Sedimentary Petrology, 50: 1219-1236.

Cachão M. (1995a) Utilização de nanofósseis calcários em biostratigrafia, paleoceanografia e paleoecologia. Aplicações ao Neogénico do Algarve (Portugal) e do Mediterãneo Occidental (ODP 635) e à problemática de Coccolithus pelagicus. Unpublished Ph.D. thesis, Fac. Sciences, University of Lisbon.

Cachão M. (1995b) Novo enquadramento estratigráfico para o Neogénico marinho do Algarve: implicações paleogeográficas e tectónicas. Univerisdade do Porto, Faculdade de Ciencias, Memória, 4: 57-61.

Cachão M. (1995c) O Neogénico do Algarve: redefinição de unidades litostratigráficas. Univerisdade do Porto, Faculdade de Ciencias, Memória, 4: 63-67. 
Cachão M., Silva C.M. da (1992) Neogene Palaeogeographic evolution of Algarve Basin (Southern Portugal): a two step model. Preliminary data. Gaia, 4: 39-42.

Cachão M., Silva C.M. da (2000) The three main marine depositional cycles of the Neogene of Portugal. Ciências da Terra (UNL), 14: 303-312.

Cachão M., Silva C.M. da (2002) Guia de Saida de Campo ao Neogénico do Algarve. VI Encontro Nacional de Estudantes de Geociências, Algarve, Lisboa.

Cachão M., Boski T., Moura D., Silva C.M. da, Santos A., Pimentel N., Cabral J. (1998) Proposta de articulaçăo das unidades sedimentares neogénicas e quaternaries do Algarve (Portugal). Actas do V Congresso National de Geologia (Resumos alargados). Comunicaçoes do Insituto Geológico e Mineiro, 84 (1): A169-A172.

Calzada S. (1995) Una nueva subespcie de bivalvo en el Mioceno marino catalan. Acta Geologica Hispanica, 20 (2): 187-190.

Carter J.G. (1990) Evolutionary significance of shell microstructure in the Palaeotaxodonta, Pteriomorphia and Isofilibranchia (Bivalvia: Mollusca). In: Skeletal Biomineralization: Patterns, Processes and Evolutionary Trends, 1 (ed. J.G. Carter): 136-296. Van Nostrand Reinhold, New York.

Chavan A. (1940) Les fossils du Miocene superieur de Cacela. Comunicação dos Serviços Geológicos du Portugal, 21: 61-106.

Chavan A. (1944) Etude complementaire de la faune de Dar-Bel-Hamri. Bulletin de la Societe Geologique de France, 5 Serie, 14: 155-171.

Choffat P. (1950) Géologie du Cénozoique du Portugal. Comunicação dos Serviços Geológicos du Portugal, Suppl. ao Tomo 30: 9-182.

Cossmann M., Peyrot A. (1909-1912) Conchologie néogénique de l'Aquitaine, I: Pélécypodes (Clavagellidae a Lúcinidae). Saugnac, Bordeaux.

Denison R.E., Koepnick R.B., Fletcher A., Howell M.W., Calloway W.S. (1994) Criteria for the retention of original seawater ${ }^{87} \mathrm{Sr} /{ }^{86} \mathrm{Sr}$ in ancient shelf limestones. Chemical Geology, 112: 131-143.

Dollfus G.F., Berkeley Cotter J.C. (1909) Mollusqes Tertiaires du Portugal. Le Pliocene au nord du Tage (Plaisancien). $1^{\text {re }}$ partie Pelecypoda. Commission du Service Géologique du Portugal, Lisbonne.

Dollfus G.F., Berkeley Cotter J.C., Gomes J.P. (1903) Planches de cephalopods, gastropods et pelecypodes laissees par F.A. Pereira da Costa accompagnees d'une explication. In: Mollusqes Tertiaires du Portugal (eds. G.F Dollfus, J.C. Berkeley Cotter and J.P Gomes, 1903-1904): 26-55. Academia real das sciencias, Lisbonne.

Esteban M., Braga J.C., Martin J.M., Santisteban C. (1996) Western Mediterranean reef complexes. SEPM Concepts in Sedimentology and Paleontology, 5: 55-72.

Freneix S. (1957) Lamellibranches nouveaux du Miocene du Portugal. Comunicação dos Serviços Geológicos du Portugal, 37: 227-239.

Glibert M., Van de Poel L. (1965-1970) Les bivalves fossiles du Cénozoique étranger des collections de l'Institut Royal des Sciences naturelles de Belgique. Mémoires de l'Institut Royal des Sciences naturelles de Belgique, 2 série, 77: 1-112; 78: 1-105; 81: 1-82; 82:1-108; 83: 1-152; 84: 1-185.

Gonzáles Delgado J.A., Andres I., Sierro F.J. (1995) Late Neogene molluscan faunas from the Northeast Atlantic (Portugal, Spain, Morocco). Geobios, 28: 459-471.

Hodell D.A., Woodruff F. (1994) Variations in the strontium isotopic ratio of seawater during the Miocene. Stratigraphic and geochemical implications. Paleoceanography, 9: 405-426.

Howarth R.J., McArthur J.M. (1997) Statistics for Strontium Isotope Stratigraphy: a robust LOWESS fit to the marine Sr-isotope curve for 0 to $206 \mathrm{Ma}$, with look-up table for derivation of numeric age. Journal of Geology, 105: 441-456.

International Chronostratigraphic Chart (2012) International Commission on Stratigraphy, August 2012. www.stratigraphy.org
Kralik K. (1984) Effects of cation-exchange treatment and acid leaching on the Rb-Sr system of Illite from Fithian, Illinois. Geochimica et Cosmochimica Acta, 48: 527-533.

Kullberg J.C., Manuppella G., Pais J. (1992) Aspectos da tectónica alpina no Algarve. Ciências da Terra (UNL), 11: 293-302.

Lacour D., Lauriat-Rage A., Saint Martin J.-P., Videt B., Neraudeau D., Goubert E., Bongrain M. (2002) Les association de bivalves (Mollusca, Bivalvia) du Messinien du bassin de Sorbas (SE Espagne). Geodiversitas, 24 (3): 641-657.

Lauriat-Rage A., Brebion Ph., Cahuzac B., Caix Ch., Ducasse O., Ginsburg L., Janin M.-C., Lozouet P., Margerel J.-P., Nascimento A., Pais J., Poignant A., Pouyet S., Roman J. (1993) Palaeontological data aboyt the climatic trends from Chattian to present along the Northeastern Atlantic frontage. Ciências da Terra (UNL), 12: 167-178.

Lauriat-Rage A., Ben Moussa A., Piquet J.-P., Saint Martin J.-P. (1999) The Bivalvia (Mollusca) from the Upper Miocene of the Sais Basin (Southern Rifian Corridor, Morocco). Palaeobiogeography and palaeoecology. Revista de la Sociedad Geológica de España, 12 (1): 77-84.

Legoinha P. (2003) Upper Miocene planktonic foraminifera from Algarve. Chronostratigraphical implications. Ciências da Terra (UNL), 15: 199-208.

Malatesta A. (1963) Malacofauna pleistocenica di Grammichele (Sicilia). Memoire per Servire alla descrizione della Carta Geologica d'Italia, 12 (2): 199-392.

Manuppella G. (1992) Carta Geológica da Região do Algarve. Escala 1:100 000. Serviços Geológicos de Portugal, Lisboa.

Martin J.M., Braga J.C., Betzler C. (2001) The Messinian Guadalhorce Corridor; the last northern, Atlantic-Mediterranean gateway. Terra Nova, 13: 418-424.

Martini E. (1971) Standart Tertiary and Quaternary calcareous Nannoplankton zonation. In: Proceedings 2nd Planktonic Conference, Roma 1970, 2 (ed. A. Farinacci): 739-785. Tecnosciencia, Rome.

McArthur J.M. (1994) Recent trends in Strontium Isotope Stratigraphy. Terra Nova, 6: 331-358.

McArthur J.M., Howarth R.J., Bailey T.R. (2001) Strontium Isotope Stratigraphy: LOWESS Version 3: best fit to the marine Sr-isotope curve for 0-509 $\mathrm{Ma}$ and accompanying look-up table for deriving numerical age. Journal of Geology, 109: 155-170.

Monegatti P., Raffi S. (2007) Mediterranean-Middle Eastern Atlantic façade: molluscan biostarigraphy and ecobiostratigraphy through the Late Miocene. Açoreana, Supl. 5: 126-139.

Okada H., Bukry D. (1980) Supplementary modification and introduction of code numbers to the low-latitude coccolith biostratigraphic zonation (Bukry, 1973, 1979). Marine Micropaleontology, 5 (3): 171-187.

Oslick J.S., Miller K.G., Feigenson M.D., Wright J.D. (1994) Oligocene-Miocene strontium isotopes: stratigraphic revisions and correlations to an inferred glacioeustatic record Paleoceanography, 9: 427-443.

Otto J.B., Blank W.K., DahI D.A. (1988) A nitrate precipitation technique for preparing strontium for isotopic analysis. Chemical Geology (Isotope Geoscience Section), 72: 173-179.

Pais J., Legoinha P., Elderfield H., Sousa L., Estevens M. (2000) The Noegene of Algarve (Portugal). Ciências da Terra (UNL), 14 277-288.

Pais J., Cunha P.P., Pereira D., Legoinha P., Dias R., Moura D. Silveira A.B., Kullberg J.C., González Delgado J.A. (2012) The Paleogene and Neogene of Western Iberia (Portugal): a Cenozoic Record in the European Atlantic Domain. Springer Briefs in Earth Sciences, Springer, Berlin-Heidelberg.

Pereira da Costa F.A. (1866-1867) Molluscos fósseis/gastroppódes dos depósitos terciários de Portugal. (Gastéropodes des dépôts tertiaires du portugal avec la version français par M. Dalhunty). Academia real das sciencias, Lisbonne.

Pfister T., Wegmüller U. (2001) Bivalven aus der Oberen Meeresmolasse bei Bern. Teil 5. Eclogae Geologicae Helvetiae, 94: $399-426$. 
Ribeiro A., Kullberg M.C., Kullberg J.C., Manuppella G., Phipps S. (1990) A review of alpine tectonics in Portugal: foreland detachment in basement and cover rocks. Tectonophysics, 184: 357-366.

Ribeiro A., Cabral J., Babtista R., Matias L. (1996) Stress pattern in Portugal mainland and the adjacent Atlantic region, West Iberia. Tectonics, 5: 641-659.

Rico-Garcia A., Aguirre J., Civis J., González Delgado J.A., Alfonso-Gavilán G. (2006) Tafonomía cuantitativa del yacimeno de Cacela (Tortoniense superior; Algarve, Sur de Portugal). Geogaceta, 40: 207-210.

Santos A. (2000) Bivalves marinhos do Miocénico superior (Tortoniano superior) de Cacela (Algarve, Portugal). M.Sc. thesis, Universidade do Algarve, Faro (unpublished).

Santos A., Boski T. (1998) Estudo paleoecológico da Ribeira de Cacela (Miocénico superior) (Algarve): uma abordagem prelimnar. Actas do V Congresso National de Geologia (Resumos alargados). Comunicaçoes do Insituto Geológico e Mineiro, 84 (1): A157-A160.

Santos A., Mayoral E. (2007) Paleoecología de la malacofauna de bivalvos del Mioceno superior de Cacela (SE Portugal). Treballs del Museu de Geología de Barcelona, 15: 25-49.

Santos A., Marques da Silva C., Boski T., Cachão M., Cancela da Foneca L., Moura D. (2001) The palaeontological heritage of Ribeira de Cacela (Algarve, Portugal). Its preservation in the Portuguese context. Revista Española de Paleontología, $n^{\circ}$ extraordinario: 99-103.

Sanz de Galdeano C. (2000) Evolution of Iberia during the Cenozoic with special emphasis on the formation of the Betic Cordillera and its relation with the western Mediterranean. Ciências da Terra (UNL), 14: 9-24.

Schaffer F.X. (1910) Das Miocän von Eggenburg, I. Die bivalven der Miocänbildungen von Eggenburg. Abhandlungen der Kaiserlich-Königlichen Geologischen Reichsanstalt, 12 (1): 5-107.

Schultz O. (2005) Bivalvia neogenica (Nuculacea-Unionacea). In: Catalogus Fossilium Austriae (ed. W.E. Piller). Band 1/Teil 3. Verlag der Österreichischen Akademie der Wissenschaften, Wien.

Sierro F.J. (1985) The replacement of the "Globorotalia menardii" group by the Globorotalia miotumida group: an aid to recognizing the Tortonian/Messinian boundary in the Mediterranean and adjacent Atlantic. Marine Micropaleontology, 9: 525-535.

Sierro F.J., Flores J.A., Civis J., Gonzáles Delgado J.A. (1987) New criteria for the orrelation of the Andalusian and Messinian stages. Annales Instituti Geologici Publici Hungarici, 70: 355-361.

Sierro F.J., Gonzáles Delgado J.A., Dabrio C.J., Flores J.A., Civis J. (1990) The Neogene of the Guadalquivir Basin. In: Iberian Neogene Basins. Field guidebook. (eds. J. Agusti, R. Domenech, R. Julia and J. Martinell). Paleontologia i Evolucia, Memorie especial, 2: 209-267.

Sierro F.J., Flores J.A., Civis J., Gonzáles Delgado J.A., Francés G. (1993) Late Miocene globorotaliid event-stratigraphy and biogeography in the NE Atlantic and Mediterranean. Marine Micropaleontology, 21: 143-168.

Sierro F.J., Hilgen F.J., Krijgsman W., Flores J.A. (2001) The Abad composite (SE Spain): a Messinian reference section for the Mediterranean and the APTS. Palaeogeography, Palaeoclimatology, Palaeoecology, 168: 141-169.

Studencka B., Studencki W. (1988) Middle Miocene (Badenian) bivalves from the carbonate deposits of the Wójcza-Pińczów Range (southern slopes of the Holy Cross Mountains, Central Poland). Acta Geologica Polonica, 38 (1-4): 1-44.

Tavani G., Tongiorgi M. (1963) La fauna miocenica della "Arenarie di Ponsano" (Volterra, provincia di Pisa). Palaeontographia Italica, 58 (n.ser. 28): 1-41.

Tebble N. (1966) Brithis Bivalve Seashells. Alden Press Osney Mead, Oxford

Thirlwall M.F. (1991) Long-term reproducibility of multicollector Sr and $\mathrm{Nd}$ isotope ratio analysis. Chemical Geology (Isotope Geoscience Section), 94: 85-104.

Veiga Ferreira O. da (1951) Os Pectinideos do Miocenico do Algarve. Commission du Service Géologique du Portugal, 32: 153-180.

Zbyszewski G. (1957) Le Burdigalian de Lisbonne. Comunicação dos Serviços Geológicos du Portugal, 38 (1): 91-240.

Zieliński G. (2002) Interlaboratory comparability test as an indicator of quality of strontium isotopic data (in Polish with English summary). Działalność Naukowa PAN, 14: 143-145. 